\title{
Acute Respiratory Events in Connective Tissue Disorders
}

\author{
Spyros A. Papiris ${ }^{\text {a }}$ Effrosyni D. Manali ${ }^{a}$ Likurgos Kolilekas $^{\mathrm{c}}$ \\ Konstantinos Kagouridis $^{a}$ Maria Maniati $^{a}$ Gerasimos Filippatos $^{b}$ \\ Demosthenes Bouros ${ }^{d}$
}

a 2 nd Department of Pneumonology and ${ }^{\text {b}}$ 2nd Department of Cardiology, 'Attikon' University Hospital, Athens Medical School, National and Kapodistrian University of Athens, and ' 7 th Department of Pneumonology, Hospital for Diseases of the Chest 'Sotiria', and d 1st Department of Pneumonology, Hospital for Diseases of the Chest 'Sotiria', Athens Medical School, National and Kapodistrian University of Athens, Athens, Greece

\section{Key Words}

Acute 'exacerbations' in fibrotic interstitial pneumonias .

Diffuse alveolar hemorrhage syndromes · Acute pulmonary thromboembolism · Catastrophic antiphospholipid syndrome - Organizing pneumonia $\cdot$ Acute fibrinous organizing pneumonia $\cdot$ Acute hypercapnic respiratory failure $\cdot$ Myositis, ventilatory muscles $\cdot$ Pneumothorax . Pneumomediastinum · Aspiration pneumonitis - Pericarditis . Pleuropericarditis · Drug toxicity - Lung infections .

Rheumatoid arthritis · Systemic lupus erythematosus . Systemic sclerosis - Dermatomyositis-polymyositis · Primary Sjögren's syndrome · Mixed connective tissue disease . Ankylosing spondylitis

\footnotetext{
Abstract

Subacute-acute, hyperacute, or even catastrophic and fulminant respiratory events occur in almost all classic connective tissue disorders (CTDs); they may share systemic life-threatening manifestations, may precipitously lead to respiratory failure requiring ventilatory support as well as a combination of specific therapeutic measures, and in most affected patients constitute the devastating end-of-life event. In CTDs, acute respiratory events may be related to any respiratory
}

compartment including the airways, lung parenchyma, alveolar capillaries, lung vessels, pleura, and ventilatory muscles. Acute respiratory events may also precipitate diseasespecific extrapulmonary organ involvement such as aspiration pneumonia and lead to digestive tract involvement and heart-related respiratory events. Finally, antirheumatic drugrelated acute respiratory toxicity as well as lung infections related to the rheumatic disease and/or to immunosuppression complete the spectrum of acute respiratory events. Overall, in CTDs the lungs significantly contribute to morbidity and mortality, since they constitute a common site of disease involvement; a major site of infections related to the

E.D.M. and L.K. contributed equally to this work.

Previous articles in this series: 1. Bouros D, Papiris S, Cottin V: Lung involvement in rheumatic disease: introduction. Respiration 2015;90:1. 2. Papiris SA, Manali ED, Kolilekas L, Kagouridis K, Maniati M, Borie R, Pradere $P$, Crestani B, Bouros D: Investigation of lung involvement in connective tissue disorders. Respiration 2015;90:2-24. 3. Fischer A, Lee JS, Cottin V: Interstitial lung disease evaluation: detecting connective tissue disease. Respiration 2015;90:177-185. 4. Robles-Perez A, Molina-Molina M: Treatment considerations of lung involvement in rheumatologic disease. Respiration 2015;90:265-274. 5. Paschalaki KE, Jacob J, Wells AU: Monitoring of lung involvement in rheumatologic disease. Respiration 2016;91:89-98.

\section{KARGER}

E-Mail karger@karger.com www.karger.com/res
(C) 2016 S. Karger AG, Basel

0025-7931/16/0913-0181\$39.50/0
Prof. med. Spyros A. Papiris

2nd Department of Pneumology, 'Attikon' University Hospital

1 Rimini Street

GR-12462 Haidari, Athens (Greece)

E-Mail papiris@ otenet.gr 
'mater' disease; a major site of drug-related toxicity, and a common site of treatment-related infectious complications. The extreme spectrum of the abovementioned events, as well as the 'vicious' coexistence of most of the aforementioned manifestations, requires skills, specific diagnostic and therapeutic means, and most of all a multidisciplinary approach of adequately prepared and expert scientists. Avoiding lung disease might represent a major concern for future advancements in the treatment of autoimmune disorders.

(C) 2016 S. Karger AG, Basel

\section{Introduction}

Subacute-acute, hyperacute, or even catastrophic and fulminant respiratory events occur in the ambit of almost all classic connective tissue disorders (CTDs); they may share systemic life-threatening manifestations, may precipitously lead to respiratory failure - in most cases requiring ventilatory support - as well as a combination of specific therapeutic measures, and in most affected patients constitute the devastating end-of-life event [1-10].

In CTDs, acute respiratory events may be related to any respiratory compartment such as (a) the airways [e.g. acute infective exacerbations in bronchiectatic patients with rheumatoid arthritis (RA) [11]]; (b) the lung parenchyma [e.g. the development of diffuse alveolar damage (DAD) upon fibrotic interstitial lung disease (ILD), mainly usual interstitial pneumonia (UIP), but also fibrotic nonspecific interstitial pneumonia (f-NSIP) clinically manifesting as the development of acute respiratory distress syndrome (ARDS) upon chronic fibrotic ILD, or the development of organizing pneumonia $(\mathrm{OP})$ or acute fibrinous OP (AFOP) [12]]; (c) the alveolar capillaries [e.g. diffuse alveolar hemorrhage (DAH), acute capillaritis, or bland hemorrhage related to systemic lupus erythematosus (SLE) [13]]; (d) the lung vessels [e.g. acute pulmonary thromboembolism or the development of a catastrophic antiphospholipid syndrome (CAPS) in SLE [14]]; (e) the pleura [e.g. pneumothorax and/or pneumomediastinum mostly in dermatomyositis-polymyositis (DM-PM) [15]], and (f) the ventilatory muscles (e.g. the development of acute hypercapnic respiratory failure related to acute ventilatory muscle myositis in DM-PM [16]). In addition, acute respiratory events may precipitate diseasespecific extrapulmonary organ involvement such as aspiration pneumonia as well as the far less frequently occurring Mendelson syndrome with digestive tract involvement, mainly in scleroderma and DM-PM [1719] as well as in acute heart-related respiratory events in myocarditis or pericarditis with tamponade [20]. Last but not least, acute antirheumatic drug-related respiratory toxicity as well as acute lung infections related to the 'mater' disease, specific manifestations of rheumatic disease in the lung, and/or immunosuppressive treatment (including the widespread use of biological factors) complete the spectrum of acute respiratory events in CTDs (table 1) [4, 21-24].

Acute respiratory events rarely occur in early, undiagnosed, or undefined CTDs, facilitating the diagnostic approach and therapeutic decision-making, but the preexistence of other chronic lung manifestations of the mater disease, such as bronchiectasis or fibrotic ILD, clearly predisposes patients to the development of infective or drug-related lung events - especially those patients who need treatment according to any dosage schedule with steroids, cytotoxic agents, and the most recently developed biological factors (monoclonal antibodies, receptor analogs, and chimeric molecules) [25-28]. The common denominator upon which immunosuppression acts and precipitates respiratory infections is the existence of an altered and aggressive lung microbiome in chronically disrupted lungs [29]. Indeed, there is considerable concern regarding the initiation of treatment for RA with biological, disease-modifying factors in case of an already established lung disease, especially in the case of ILD and bronchiectasis; several experts advise 'careful counseling and patients' consent regarding the risks and benefits' [30]. The extreme spectrum of the abovementioned acute respiratory events, as well as the 'vicious' coexistence of most of the aforementioned manifestations where specific treatment for one disease manifestation may be deleterious with regard to a coexistent respiratory manifestation, requires skills, specific diagnostic and therapeutic means, and most of all a multidisciplinary approach of adequately prepared and expert scientists [31].

\section{Acute ‘Exacerbations' Developing upon Fibrotic ILDs}

The superimposition of DAD of unknown etiology upon UIP histology has been described in idiopathic pulmonary fibrosis (IPF) by Kondoh and coworkers since 1993 and clinically represents the development of a devastating end-of-life ARDS [32, 33]. Kondoh et al. [33] were also the first to pose the fundamental question of whether the above-described condition represents an accelerated phase of the same disease or ARDS of any etiology developing upon disruption of the diseased lung, opting for the first hypothesis and suggesting steroids for its 
Table 1. Acute respiratory events in CTDs

\begin{tabular}{llllllll}
\hline Manifestation & RA & SLE & SSc & DM-PM & pSS & MCTD & AS \\
\hline ILD 'acute exacerbation' & + & - & + & ++ & - & $?$ & - \\
OP & + & + & + & ++ & - & + & - \\
AFOP & \pm & \pm & \pm & \pm & - & - & - \\
DAH & \pm & + & \pm & \pm & - & - & - \\
Venous thromboembolism & \pm & ++ & - & - & - & \pm & - \\
Catastrophic APS & - & + & - & - & - & - & - \\
Bronchiectasis exacerbation & ++ & - & - & - & + & - & - \\
PNX-pneumomediastinum & \pm & - & - & + & \pm & - & \pm \\
Aspiration pneumonia & - & - & ++ & ++ & - & \pm & - \\
Hypercapnic respiratory failure & - & \pm & - & ++ & - & - & - \\
Pericarditis & \pm & ++ & \pm & \pm & \pm & \pm & - \\
Pulmonary infections & + & +++ & + & + & + & + & + \\
Drug toxicity & ++ & +++ & ++ & ++ & + & ++ & + \\
\hline
\end{tabular}

SSc = Scleroderma; pSS = primary Sjögren's syndrome; MCTD = mixed CTD; AS = ankylosing spondylitis; APS = antiphospholipid syndrome; PNX = pneumothorax.

management. A more recent consensus report fully adopted the above suggestion and named the whole condition 'IPF acute "exacerbation"', suggesting high-dose steroids for its management, a consensus also encountered in all subsequent guidelines on IPF [34, 35]. The suggestion to use high-dose steroids, as well as the poor response observed in most if not all cases, was interpreted by some clinicians as the necessity to push for an even more profound immunosuppression, and several cytotoxic agents were added on a case-by-case basis, again failing to prove any clear benefit [36-38]. The rising concern regarding the disappointing results of this therapeutic approach for so-called IPF acute 'exacerbations' and the necessity of an alternative approach have been voiced in the publications by our group of investigators since 2010; moreover, treatment of both stable and 'exacerbated' patients with steroids had been abandoned in our clinical practice more than a decade before that time $[32,39]$. The more recent publication of the PANTER study on IPF - conducted under the auspices of the IPF Clinical Research Network (IPFnet) and proving for the first time that immunosuppression in IPF leads to infections, hospitalizations, 'exacerbations', and death - renders it inconceivable that even higher doses of steroids are used hoping for improvement in IPF patients already on treatment with steroids and cytotoxic drugs and developing ARDS [40]. Indeed, an even more recent study by Papiris et al. [41] showed that abolishing steroids in IPF patients developing ARDS may prove to be of benefit, and that a history of steroid use as the standard of care for these patients before ARDS development abolishes this benefit and clearly predisposes to death.

After the first description of the development of DAD upon UIP in IPF, several reports have referred to the development of DAD upon other fibrotic ILDs, including idiopathic NSIP and fibrotic-phase established extrinsic allergic alveolitis, and also fibrotic ILDs of both the UIP type and the NSIP type in patients suffering from CTD (mainly RA, but also others), approaching a cumulative incidence of around 7\% (fig. 1) [12, 42, 43]. In CTDrelated fibrotic ILDs, an even greater matter of concern regarding the development of DAD in damaged fibrotic lungs arises, since most of the patients with such diseases not only are on treatment with combinations of steroids and cytotoxic drugs (synthetic disease-modifying drugs) such as azathioprine, methotrexate, cyclosporine, or others but also extensively use biological disease-modifying drugs such as TNF- $\alpha$ inhibitors (infliximab, etanercept, adalimumab, golimumab, or certolizumab pegol), an anti-IL-6 receptor monoclonal antibody (tocilizumab), Tcell signaling inhibitors (abatacept), an anti-CD20 monoclonal antibody (rituximab), or others [44]. Indeed, the extensive use of biological factors in CTDs over the past few years has been paralleled by an exponentially rising number of reports on the development of several types of lung toxicity, such as de novo development of chronic and/or acute ILD, 'exacerbation' of preexisting chronic fibrotic ILD, and finally significant infective lung and systemic toxicity [45-47]. On the other hand, similar types of lung toxicity have clearly been reported with the exten- 
Fig. 1. HRCT images of the chest revealing subpleural interstitial thickening and areas of ground-glass attenuation together with some bronchial distortion and esophageal dilatation $(\mathbf{a}, \mathbf{b})$. The patient was a 62 -yearold woman, a never-smoker with a longstanding history of scleroderma. After a few months, she experienced progressive dyspnea that led to severe hypoxemia; at that point, an HRCT of the chest demonstrated extensive areas of ground-glass attenuation, small focal areas of consolidation, irregular linear opacities, and traction bronchiectasis/bronchiolectasis in the lower lobes and particularly in the subpleural regions compatible with an acute 'exacerbation' upon the preexisting fibrotic ILD (c, d).
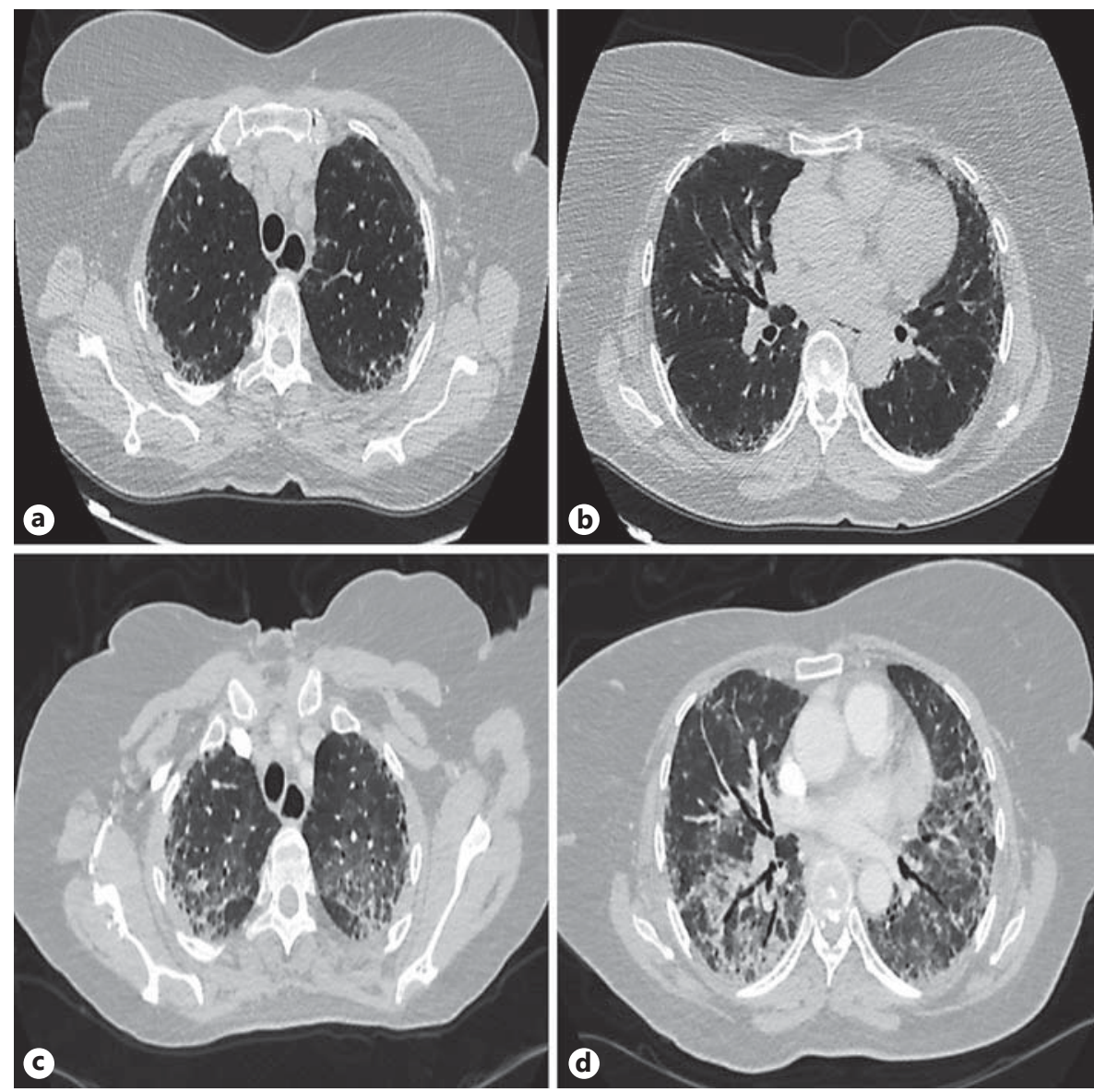

sive use of synthetic disease-modifying drugs, especially methotrexate $[48,49]$. Therefore, the current common practice of combination treatment with both synthetic and biological disease-modifying drugs bears a considerable risk of acute drug toxicity, in particular if applied upon preexisting fibrotic ILD. Finally, the ineffectiveness or inadequacy of both synthetic and biological diseasemodifying drugs in influencing the appearance or deterioration of preexistent CTD-related fibrotic ILDs becomes even more obvious since many patients were developing fibrotic ILDs even though they were already in treatment with the abovementioned drugs.

Actually, the pathogenesis and treatment of the development of DAD upon idiopathic fibrotic ILDs, and per extrapolation of 'exacerbations' upon CTD-related fibrotic ILDs, are reconsidered for several reasons including (a) the ineffectiveness and probably deteriorating effect of immunosuppressive treatment on ARDS, (b) the fact that an infective etiology for the development of ARDS upon fibrotic ILDs can never be excluded, (c) the fact that cur- rent treatment of CTDs, as well as in many cases of the mater disease, predisposes to lung infections, and (d) the fact that damaged and disrupted lungs become hosts to an altered human microbiome. Therefore, a multidisciplinary approach should be warranted for any patient and at any level of therapeutic decision-making including (a) the initiation of treatment on preexisting ILDs and the obligatory 'careful counseling and patients' consent regarding the risks and benefits' [30], (b) the diagnostic approach upon acute deterioration such as the development of ARDS upon fibrotic CTD-related ILDs, and (c) therapeutic decisions in a clinical context in which infections are difficult to detect and may never be excluded [50].

\section{Acute Lung Infections in CTDs}

Acute lung infections rank very high on the list of both common and detrimental acute respiratory events in CTDs, and they often constitute the most common etiol- 


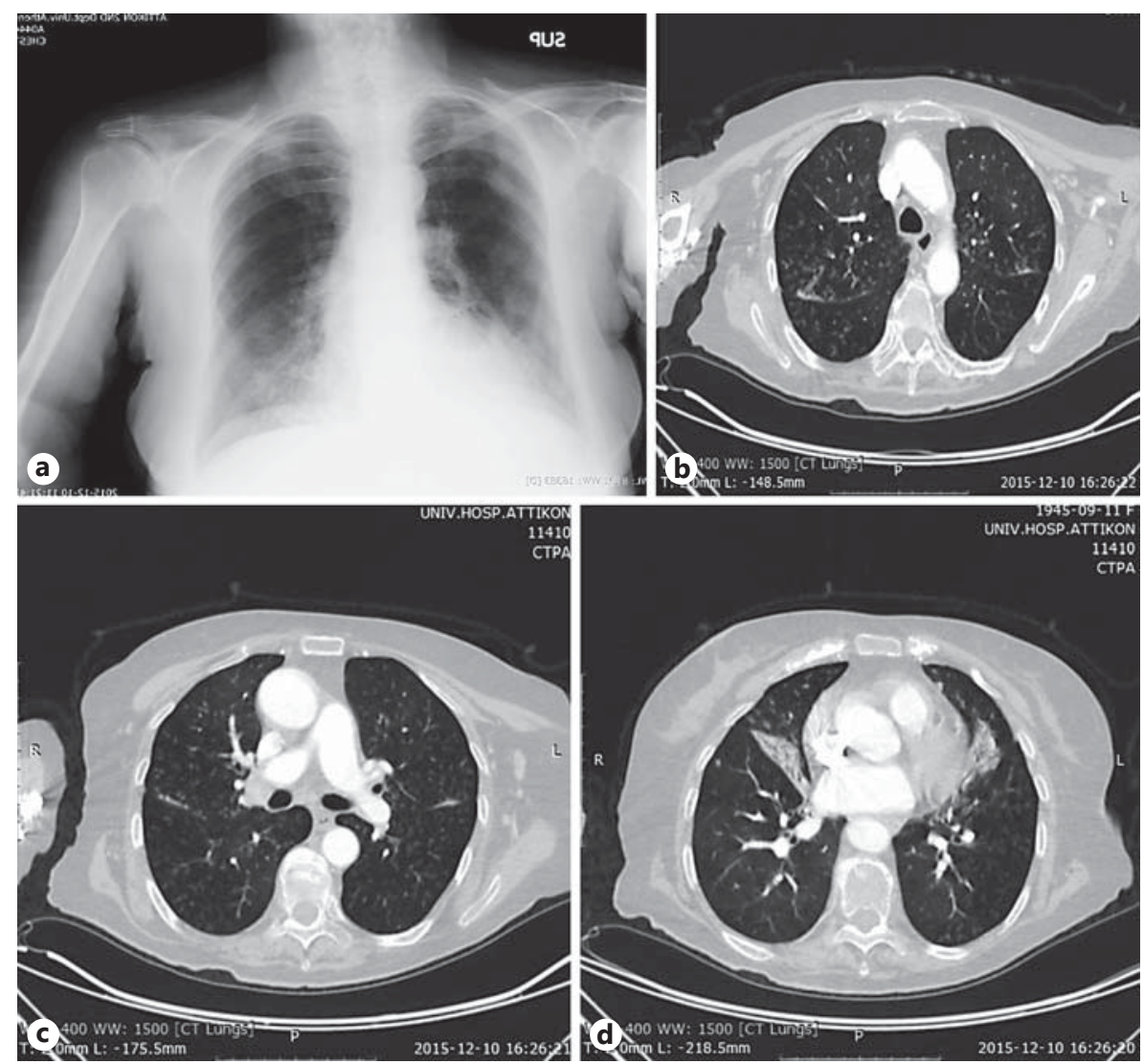

Fig. 2. a Posteroanterior chest radiograph showing reticulonodular opacities in the upper lung zones and areas of consolidation and atelectasis in the middle and lower lung zones. The patient was a 74-year-old woman with a history of long-standing RA in immunosuppressive treatment with corticosteroids. b-d HRCT images of the patient's chest demonstrating bilateral centrilobular nodular and branching opacities compatible with acute infectious bronchiolitis (b, c) upon preexisting lung bronchiectasis and cicatricial atelectasis of both the middle lobe and the lingula (d).

ogy leading to admissions of CTD patients to both hospitals and intensive care units; along with urinary tract infections, septic arthritis, septicemia, cellulites, aspiration pneumonia, and opportunistic infections in other sites, lung infections have a major impact on morbidity and mortality and are one of the three leading causes of premature death, the other two being cardiovascular events and irreparable damage to target organs [24, 25, 51-53].

Compared to the general population, the increased susceptibility of CTD patients to infections is related to three main parameters: (a) intrinsic immunological abnormalities associated with the mater CTD; (b) chronic specific CTD-related lung involvement such as bronchiectasis and fibrotic ILDs, both constituting hosts to an altered human microbiome, and (c) clinically significant immunological dysfunction induced by the use of synthetic and biological disease-modifying drugs $[4,29,54-$ 56]. Increased age and digestive tract involvement, predisposing to aspiration as in DM-PM and scleroderma, further aggravate the risk [25]. Of all CTDs, SLE presents a unique paradigm of disrupted immunity per se increasing the risk of infections attributable to the so- called lupus paradox, that is, a state of severely impaired cellular and humoral immune responses in spite of Blymphocyte hyperactivity and high levels of $\gamma$-globulins, including high antibody titers against viruses and other pathogens and a high ability to attack 'self-tissues' [26, 54, 57-59]. Recent data support an 'intrinsic' defective response to infectious agents also in RA and scleroderma $[60,61]$. Bronchiectasis is known to result from and to perpetuate a 'vicious cycle' of chronic bacterial infection and dysregulated inflammation and is therefore considered a 'high-infection-risk' condition in RA patients (fig. 2) [56]. Furthermore, recent studies have shown that fibrotic ILD is characterized by an increased distal alveolar bacterial burden that might be responsible for both a rapidly deteriorating course of fibrotic disease and deadly 'exacerbations' [29]. The establishment via new DNA sequencing technologies of the long-time hypothetic theory that a disturbed lung microbiome could trigger and/or aggravate tissue injury in susceptible pulmonary fibrosis patients bears significant importance for CTD patients not only for its role in the development and maintenance of lung disease but also 


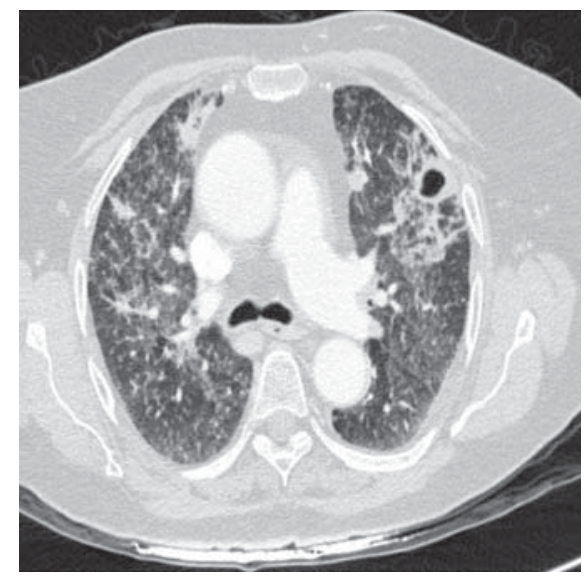

Fig. 3. CT of the chest demonstrating a thick-walled cavity in the lingula together with extensive confluent alveolar infiltrates. Acidfast bacilli were evident on microscopic sputum examination. The patient was an 83-year-old woman, a never-smoker who had longstanding RA treated with steroids and who had developed tuberculosis.

for its potential pathogenetic role in manifestations of the mater disease [62-64].

On top of the already described immune dysregulation and lung parenchymal structural changes, traditional and novel biological therapies - although indispensable for the management of systemic manifestations of several CTDs - further enhance the risk of infection by suppressing immune responses. Corticosteroids, for example, suppress both humoral and cellular immunity and have been shown to increase the infection rate by a factor of $2-4$ at any dose, with doses of more than $20 \mathrm{mg}$ prednisone per day having the most deleterious effect [54, 65]. The rest of the disease-modifying drugs, both synthetic and biological, are also implicated in the increased risk of common, mycobacterial, and opportunistic infections. More precisely, TNF- $\alpha$ inhibitors lead to blockade of a variety of immunological functions such as cell activation and proliferation, cytokine and chemokine production, and formation and maintenance of granulomas. This is the main reason why they are related to an increased risk of granulomatous infections, chiefly tuberculosis (fig. 3). Anti-CD20 antibodies, on the other hand, cause depletion of normal B lymphocytes lasting 2-6 months, which may be implicated in disseminated viral infections (Parvovirus, Cytomegalovirus, Herpes simplex virus, Varicella zoster virus) and severe pneumonias. Coadministration of biological factors or a combination of these therapies with high doses of corticosteroids multiplies the risk of infection and should definitively be avoided, especially in elderly patients with lung comorbidities. On the other hand, upon a developed lung infection, discontinuation of immunosuppression does not lead to precipitous reconstitution of the immune system [55, 65-71]. All the above parameters significantly increase the risk of bacterial, mycobacterial, viral, and fungal pulmonary infections in CTD patients (fig. 4, 5) [23, 27, 51, 71-80].

\section{DAH Syndromes}

DAH - or, synonymously, intrapulmonary hemorrhage - designates diffuse bleeding from the pulmonary microcirculation (arterioles, alveolar capillaries, and venules) as a result of microvascular damage, leading to blood leakage into the alveolar spaces [81]. In most if not all cases, alveolar hemorrhage simultaneously affects multiple areas of both lungs, although in a minority of cases it may be less extensive at an early stage, involving one lobe or one lung, mimicking pneumonia (fig. 6, 7) [82]. Histologically, in the majority of patients alveolar hemorrhage is related to necrotizing capillaritis characterized by neutrophilic infiltration of the alveolar septa, which present expanded by both the inflammatory infiltrate and protein-rich edema. Alveolar spaces present filled with fresh blood, and in the following few days also with a high number of hemosiderin-laden macrophages (fig. 8). Occasionally, arteriolitis and venulitis may coexist [83]. In a minority of patients with pulmonary hemorrhage, capillaritis may be absent and defines a bland pulmonary hemorrhage $[84,85]$.

With regard to CTDs, alveolar hemorrhage occurs mainly in SLE (affecting 2-5\% of lupus patients) and usually presents fulminant and catastrophic, occurring within hours or, in a minority of cases, in the space of a few days [57]. Clinically, it manifests as dyspnea, cough, and hemoptysis (may be absent in as much as $30 \%$ of patients) and usually coexists with lupus nephritis $[13,86]$. In a significant proportion of patients, severe respiratory failure may develop, requiring ventilatory support and intensive care unit stay [87]. For a diagnosis of alveolar hemorrhage, the subsequent criteria should be fulfilled: (a) chest X-ray- or CT-proven bilateral and confluent alveolar shadows, (b) a new drop in hematocrit or hemoglobin levels (more than 1.5-2 g/dl), and (c) pink or red bronchoalveolar lavage fluid becoming increasingly red on successive aliquots (fig. 9) [84, 85]. An 'active' urinary sediment including the detection of dysmorphic ('Mickey Mouse') red cells strongly suggests the simultaneous oc- 
Fig. 4. HRCT of the chest revealing extensive areas of consolidation with the presence of an air bronchogram in the right lung along with alveolar infiltrates in the left lung $(\mathbf{a}, \mathbf{b})$. The patient was an 80 -yearold woman with long-standing RA in treatment with steroids who presented with purulent sputum, fever, and severe hypoxemia. The clinical and laboratory features were consistent with severe pneumonia complicated by septic shock.
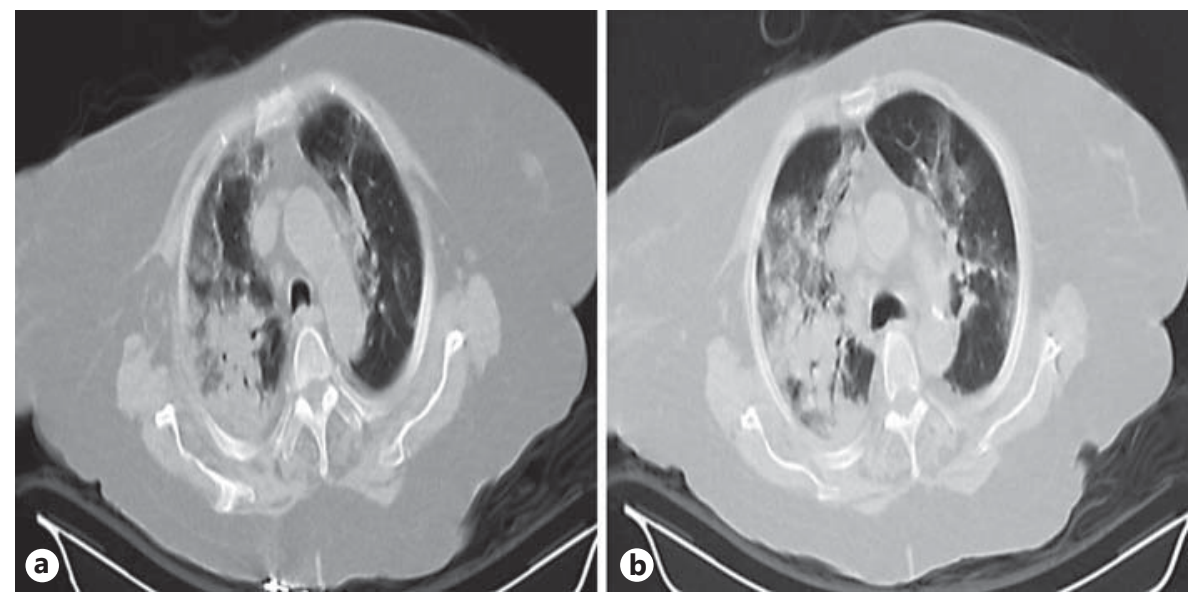

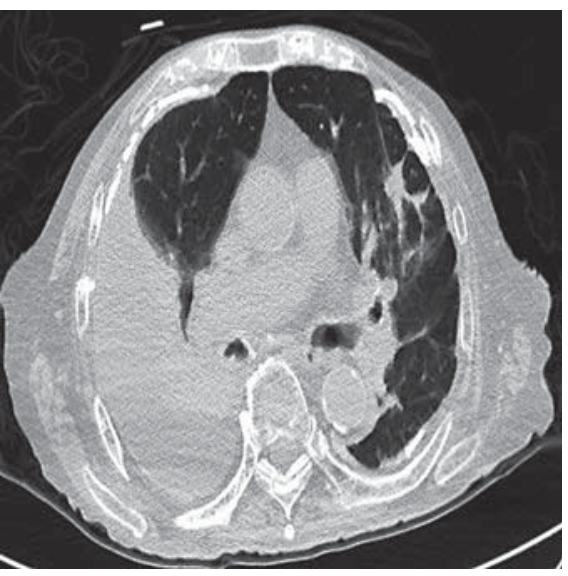

Fig. 5. CT of the chest revealing pleural effusion with passive atelectasis of the right lower lobe associated with consolidation of the left lung and pleural calcifications. The patient was a 78-year-old man, an ex-smoker with long-standing RA treated with methotrexate and steroids who presented with purulent sputum, fever, agitation, and hypoxemia. Pleural fluid cultures grew Listeria monocytogenes.

currence of lupus nephritis $[84,85]$. In the hands of a well-trained and expert physician, assessment of the above criteria does not need an excessive amount of time; this ensures a prompt diagnosis in order to provide appropriate treatment, both of which are of paramount importance for the achievement of a good outcome [87]. Indeed, early diagnosis and timely administration of treatment appear to have favorably influenced the prognosis of such patients; a few decades ago, the mortality rate had approached approximately $90 \%$ (fig. 10). In lupus patients, thrombocytopenia appears to be significant- ly associated with the emergence of alveolar hemorrhage. Treatment consists of the administration of pulses of steroids and cyclophosphamide as early as possible [87]. In the past years, other therapeutic options have emerged, such as plasmapheresis, the administration of intravenous immunoglobulins, rituximab, mycophenolate mofetil, recombinant factor VII, and others, permitting a more individualized treatment according to the immunological status and general condition of the patient [88-94].

\section{Pulmonary Thromboembolism and CAPS}

As already stated, 'pulmonary thromboembolism (PTE) is the third most characteristic respiratory manifestation in SLE patients appertaining to the spectrum of pulmonary manifestations of the lupus-associated antiphospholipid antibody syndrome (secondary) which also includes the chronic thromboembolic pulmonary arterial hypertension, the catastrophic antiphospholipid syndrome (CAPS) and ... others' [59, 95]. Regarding acute pulmonary thromboembolism there exist several excellent reviews and guidelines to which the reader is directed to seek advice [96]. The antiphospholipid syndrome, the clinical expression of an acquired autoimmune dysregulation, may occur per se (primary) or be associated with other clinical autoimmune conditions (secondary), mainly CTDs, among which it is encountered in SLE and far less commonly in RA [97-99]. To ensure its diagnosis, it is necessary to ascertain the clinical detection of vascular thrombosis (venous, arterial, or microvascular) and/or pregnancy morbidity (one of the 
Fig. 6. a Posteroanterior chest radiograph showing diffuse bilateral infiltrates with perihilar distribution, more prevalent in the middle and lower lung fields. The patient was a 52-year-old woman, a neversmoker who fulfilled the diagnostic criteria for SLE and developed DAH. b CT image of the chest (performed at the same time) showing extensive areas of ground-glass attenuation with relative sparing of the subpleural regions.

Fig. 7. a Posteroanterior radiograph of the chest revealing consolidation with an air bronchogram of the right upper lobe mimicking lobar pneumonia. The patient was a middle-aged woman with a history of fever and shortness of breath of several days' duration. b, c Extension of infiltrates in the right lung field despite antimicrobial treatment. $\mathbf{d}$ Remission of the initial infiltrate of the right upper lobe and development of new patchy infiltrates bilaterally in the right and left lower lung fields. The patient was submitted to bronchoalveolar lavage through bronchoscopy and lung biopsy which documented DAH.
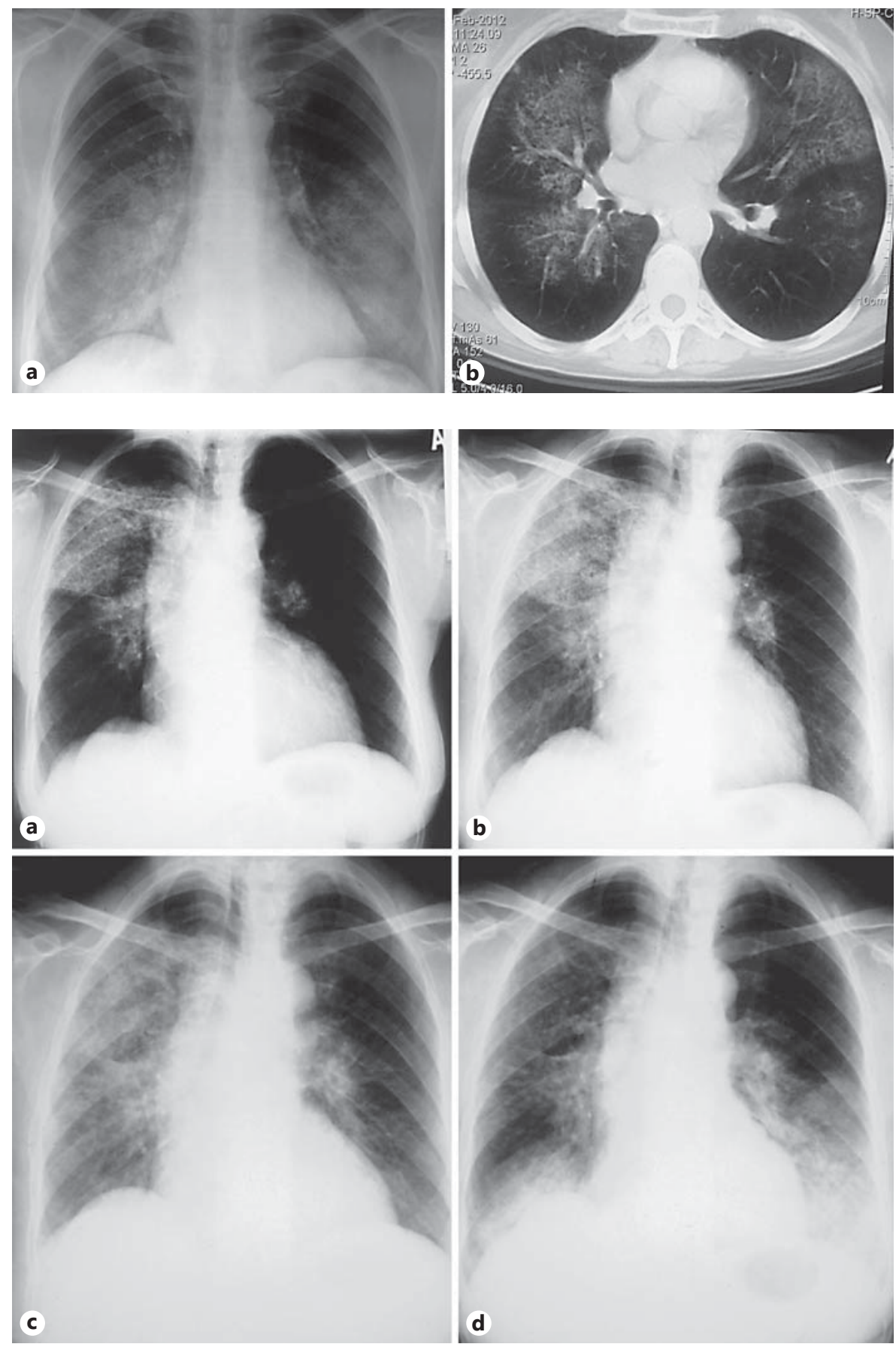

above is enough) as well as one of the following laboratory seropositivities: (1) lupus anticoagulant, (2) IgG- or IgM-isotype anticardiolipin antibodies, or (3) IgG- or IgM-isotype anti- $\beta_{2}$-glycoprotein I antibodies [100]. Pulmonary thromboembolism is the most common manifestation of venous system thrombosis, even though any venous ramification (superficial or deep) may be involved. Arterial thrombosis mainly involves the cerebral arteries, but also others. Acute and extensive microvascular thrombosis, leading to multiorgan ischemia and failure, characterizes the rarely occurring and often lethal condition named CAPS. CAPS may present as idiopathic 


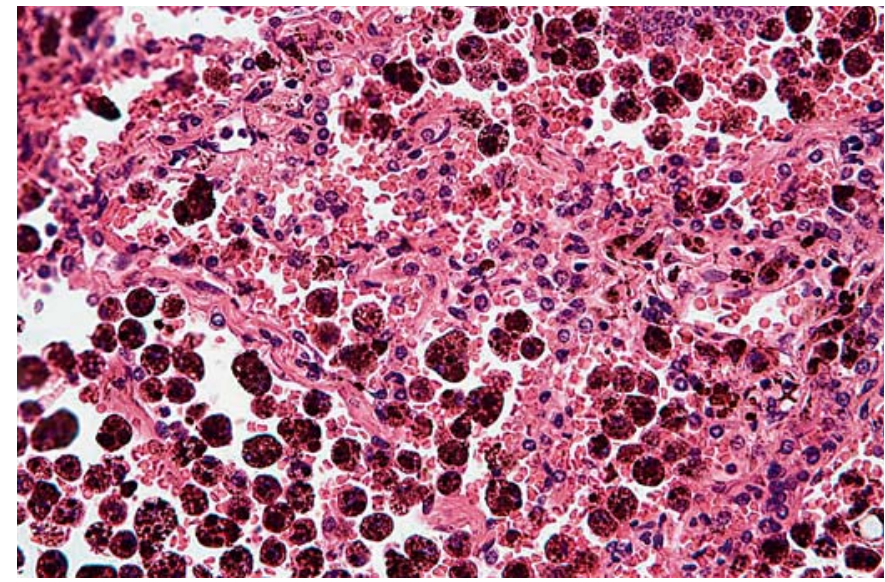

Fig. 8. Histopathological examination of the lung biopsy of a patient with DAH demonstrating air spaces filled with both fresh blood and hemosiderin-laden macrophages, highlighting the acute-on-chronic character of the hemorrhage.

or secondary, the latter form mainly occurring in female lupus patients $[14,97,98]$. It commonly involves more than three organs (more frequently the kidneys, the lungs, the central nervous system, the heart, and the liver), always presents with antiphospholipid antibodies, occurs rapidly (within less than 1 week), and is histologically characterized by intravascular thrombosis (diagnostic criteria) [101, 102]. The pathogenesis of CAPS is chiefly related to the fact that antiphospholipid antibodies inappropriately activate platelets as well as endothelial and immune effector cells, inhibit anticoagulants, inhibit fibrinolysis, and activate complement, promoting a prothrombotic and proinflammatory vascular milieu leading to widespread and multiorgan thrombosis $[103,104]$. A systemic inflammatory syndrome characterized by fever, tachycardia, tachypnea, and leukocytosis commonly coexists and is associated with the extensive ischemic tissue damage $[105,106]$. Triggering factors identified in most patients include infections, surgery, obstetric complications, drugs or discontinuation of anticoagulants, and others $[107,108]$. The clinical manifestations are related to the specifics of organ involvement and include severe hypertension, acute renal failure, proteinuria, and hematuria (kidneys); ARDS, pulmonary embolism, and DAH (lungs); hypertensive and/or ischemic encephalopathy and stroke (central nervous system); coronary artery thrombosis and valve lesions (heart), and livedo reticularis, acrocyanosis, purpura, and others (skin) $[109,110]$. Prompt treatment with anticoagulants, immunosuppressants, intravenous immunoglobulins, plasmapheresis,
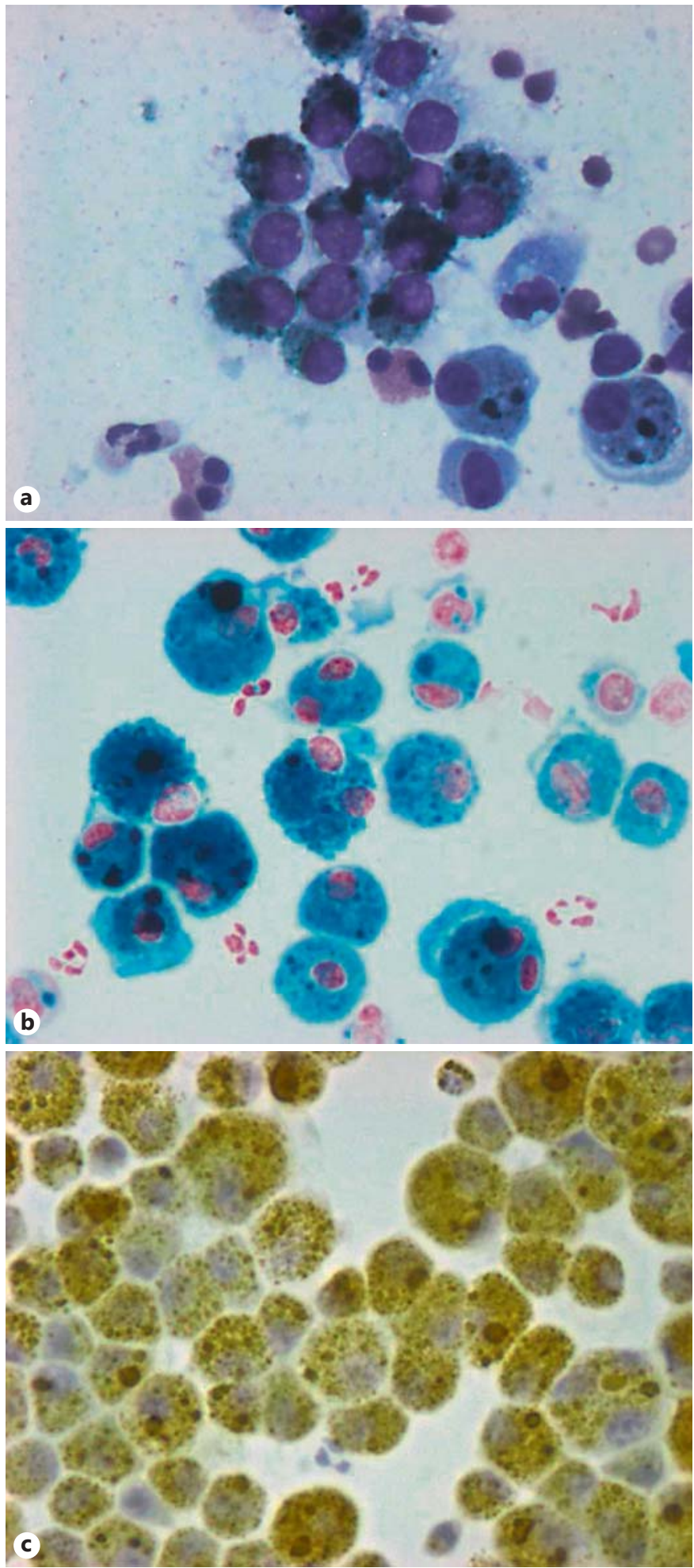

Fig. 9. Cytological bronchoalveolar lavage fluid stains showing hemosiderin-laden macrophages in a patient with DAH. $\times 400$. a Giemsa stain. b Perls stain. c Papanicolaou stain. 

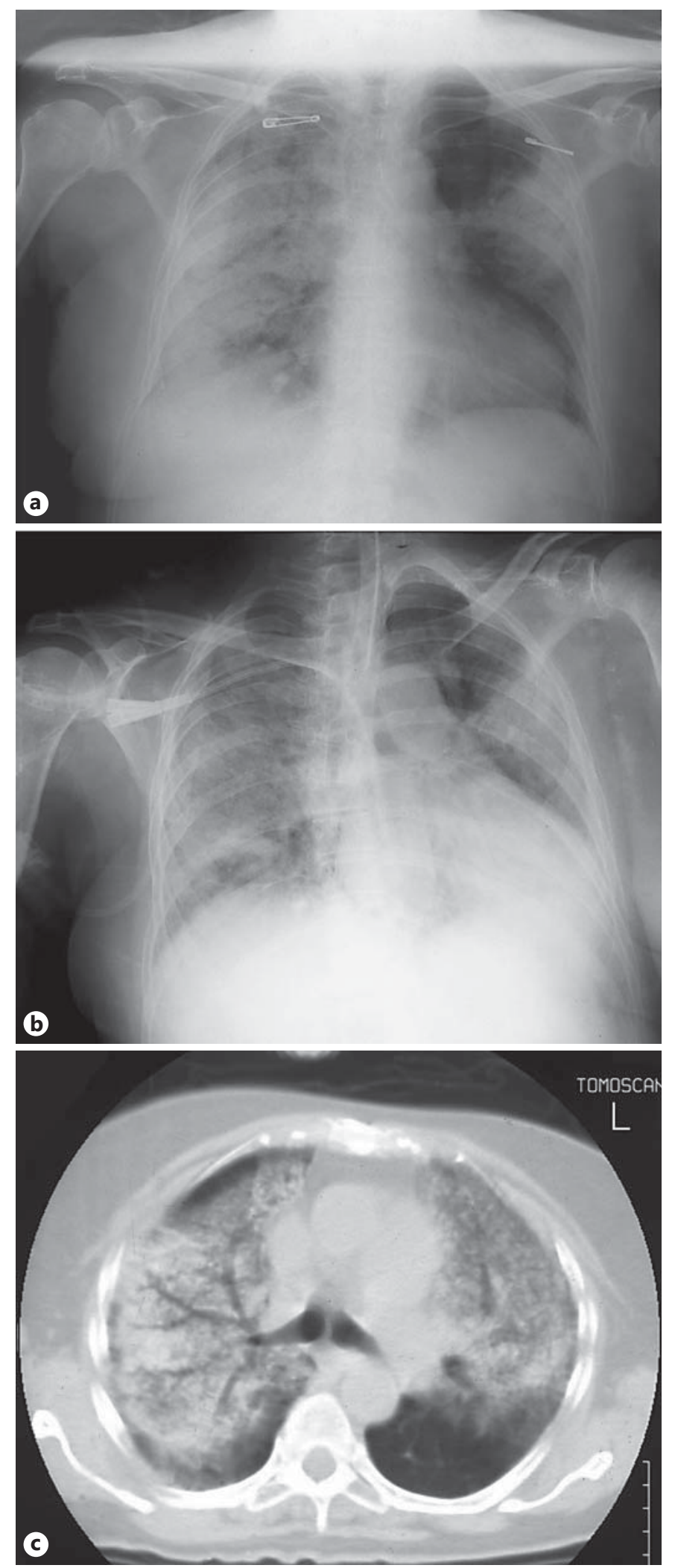

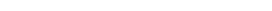

and antiplatelet agents - all of the above using antibiotic coverage as well as a multidisciplinary approach including intensivists - may favorably affect the outcome [111113].

\section{OP and AFOP}

$\mathrm{OP}$ is a sort of subacute-acute lung injury occurring in a number of different settings such as infections, adverse drug reactions, inhalation of toxic gases and dusts, neoplasms, radiation exposure, aspiration, CTDs or even idiopathic diseases, and others [114-117]. It is synonymous with bronchiolitis obliterans OP and histologically represents a process in which distal bronchioles and the air space are filling with elongated fibroblasts and myofibroblasts intertwined with several inflammatory cells in a myxoid matrix forming plugs or polyps (Masson bodies or 'bourgeons conjonctives') [114, 118]. Occasionally, in surgical specimens, proteinaceous or fibrinous (fibrin 'ball') exudates may predominate, clinically characterizing a more severe condition named AFOP by some investigators and lying between OP and ARDS [119]. AFOP may occur in a number of clinical settings as OP, and the fact that on histological examination remnants of both acute and chronic inflammatory cells coexist, as well as that AFOP occurs in immunocompromised patients, may suggest an infectious etiology [119]. Both OP and AFOP share ultrastructural changes with DAD, which emphasizes similarities in their pathogenesis and their role in processes of acute lung injury, even though they show a different geographical extension in the lung and prognosis $[119,120]$. In some patients, the overlapping of $\mathrm{OP}-\mathrm{AFOP}$ and ARDS, as occurring in CTDs, may suggest a common immunological, infective, or other etiology $[117,119,121,122]$.

In CTDs, OP and AFOP may be the initial manifestation, set in simultaneously, or develop during clinical progression of the mater disease; in the last case, they may coexist with other forms of respiratory involvement or an already developed adverse drug reaction $[59,114,117$,

Fig. 10. a Radiograph of the chest of a patient with rapidly progressing DAH revealing extensive consolidation of both lungs. b Radiograph of the same patient a few hours later after endotracheal intubation and mechanical ventilation due to severe respiratory failure. c The patient underwent CT of the chest, demonstrating numerous poorly defined, confluent centrilobular opacities in both lungs, and deceased a few days later in the intensive care unit despite aggressive treatment.
Papiris/Manali/Kolilekas/Kagouridis/ Maniati/Filippatos/Bouros 
Fig. 11. a, b HRCT scans of the chest showing areas of ground-glass attenuation together with focal areas of consolidation, principally in the lower lobes. The patient was a 72-year-old woman, a never-smoker with mixed connective tissue disease who had developed AFOP. c Histopathological examination of the lung biopsy of the same patient depicting AFOP with diffuse lung involvement. HE. $\times 4$. d Intra-alveolar spaces are filled with fibrin in the form of 'fibrin balls', whereas the intervening lung parenchyma shows minimal changes, mostly mild inflammatory infiltrates and minimal interstitial widening. HE. $\times 10$.
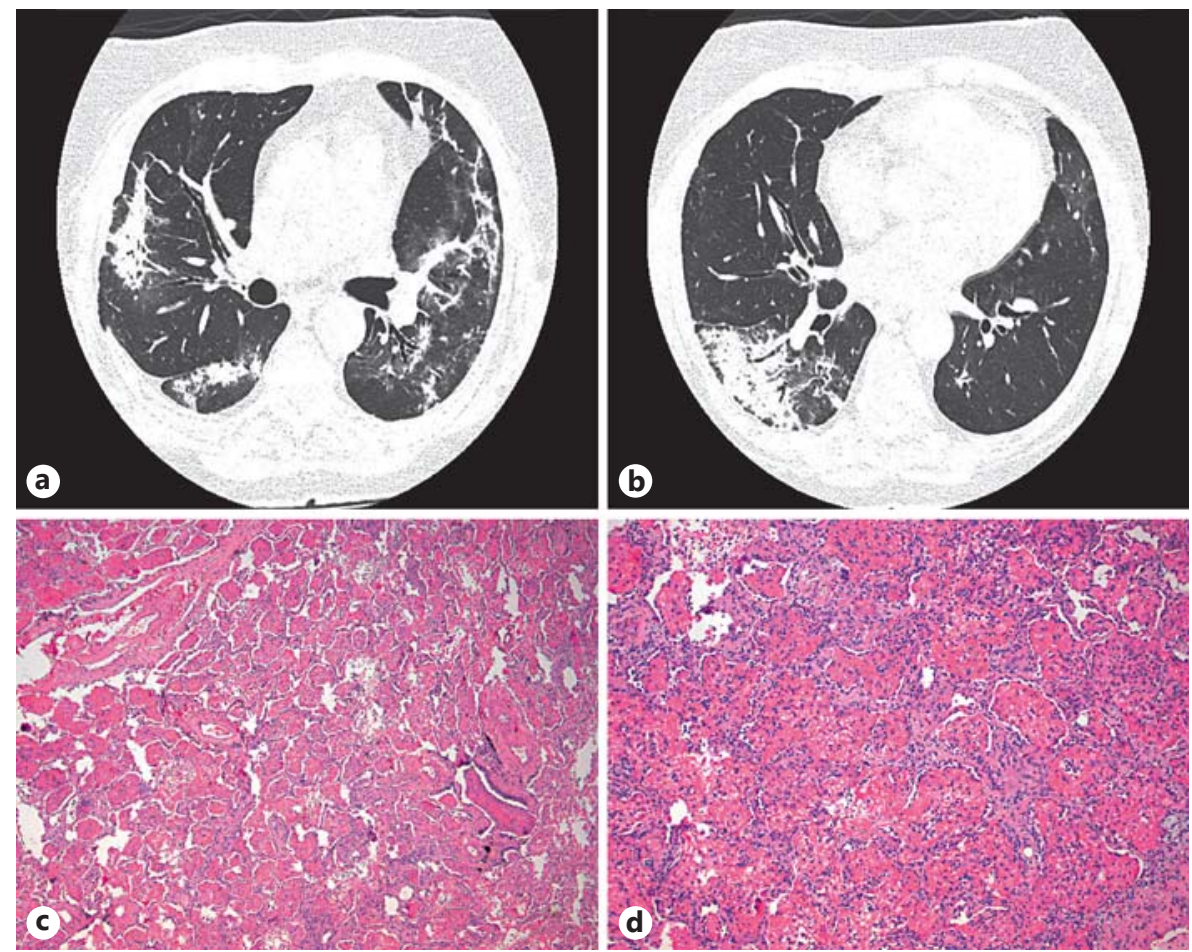

119-121, 123, 124]. OP and AFOP associated with various CTDs share clinical, radiographic, and histopathological features with idiopathic OP and AFOP (fig. 11) $[121,123]$. CTD-related OP has been described in almost all CTDs, although more frequently in RA and DM-PM, and has a female predominance $[121,123]$. In comparison to idiopathic OP, patients with CTD-OP present more commonly with autoantibodies and higher levels of inflammatory indices [121]. Occasionally, OP sets in during an episode of a CTD flare-up, suggesting an underlying, shared immunological mechanism [123]. The clinical outcome of CTD-OP has not been well defined, even though various studies have reported a worse prognosis, a lower complete recovery rate, and a tendency towards higher recurrence rates as compared to the idiopathic form $[121,123]$. In RA, OP represents up to $10-15 \%$ of any ILD involvement and is often observed during the follow-up of joint-associated symptoms, but in rare cases it can predate the development of joint manifestations or serological conversion, which may lead to underdiagnosis and missing of the link between OP and underlying but early and undiagnosed RA [123, 125-127]. In DM$\mathrm{PM}, \mathrm{OP}$ is an even more common manifestation, with its reported prevalence approaching $20 \%[125,128,129]$. In $\mathrm{PM}, \mathrm{OP}$ commonly occurs in the ambit of the antisynthe- tase syndrome and may coexist with an underlying and already established f-NSIP $[125,129]$. Furthermore, in clinically amyopathic dermatomyositis (CADM), characterized by minimal or absent muscle involvement and anti-CADM-140 antibody seropositivity, OP has been described to occur as a more rapidly progressive respiratory disease often overlapping with DAD [59, 130-132]. In general, OP in DM-PM appears to carry a less favorable prognosis, and some clinicians advocate a more profound immunosuppressive treatment - although an infective etiology is impossible to exclude also in this setting [121, $123,125]$. OP is an unusual manifestation in SLE, and only few reports have been documented [123, 125].

AFOP has recently been recognized as a distinct pattern of lung injury, and two clinical forms have been described: an acute form, with fulminant presentation overlapping with ARDS, leading to death in most if not all patients, and a subacute form, with a more favorable outcome [119]. There are only single case reports of documented AFOP in DM-PM, ankylosing spondylitis, and mixed connective tissue disease [133-136]. As the assessment of AFOP is essentially histological, needing large biopsy specimens, surgical lung biopsy is essential for the diagnosis and the early institution of appropriate treatment [119]. 


\section{Acute Hypercapnic Respiratory Failure Related to Acute Ventilatory Muscle Myositis}

Inflammatory myopathy has been described in all of the CTDs [16]. However, when it occurs in diseases other than DM-PM and SLE (far less frequently), myositis tends to be mild and never predominates in the clinical expression [137]. Inflammatory myositis leads to muscle weakness, muscle tenderness, sometimes pain, and ultimately atrophy and fibrosis. In inflammatory myopathies, the proximal muscles of the legs are affected first, followed by the proximal arm muscles and the trunk [16]. Often, but characteristically in DM-PM, involvement of the thoracoabdominal ventilatory pump muscles may predominate or co-occur with generalized muscle involvement and leads to a more or less rapidly evolving hypercapnic respiratory failure necessitating ventilatory support [137-140]. In this clinical context, both inspiratory and expiratory muscles are involved - and usually to the same extent $[141,142]$. The diagnosis requires a muscle biopsy, preferably an open one (because the characteristic lesions are spotty) from the quadriceps or the biceps brachii [16]. Prompt acquisition of the diagnosis is mandatory because of the precipitating or already precipitated hypercapnic respiratory failure and the necessity of obviating infections [16]. Infections are related to the coexistence of pharyngeal muscle involvement and weakness, predisposing to aspiration pneumonia and ineffectiveness of cough as well as reduced clearance of lung secretions associated with generalized thoracoabdominal muscle weakness [19, 143]. Treatment remains empirical and includes steroids and/or immunosuppressants, intravenous immunoglobulins, biological factors, and rituximab [16]. Diaphragmatic muscle involvement and related weakness may present as 'shrinking lungs and high sluggish diaphragm with clear lung fields' in lupus occurring mainly in patients without evidence of systemic myopathy [144-148]. In such a clinical context, hypercapnic respiratory failure has occasionally been reported [149]. The etiology remains unclear, although in some patients a diaphragmatic inflammatory myopathy has been documented histologically through biopsy [150152]. The therapeutic approach includes steroids and immunosuppressants $[146,147,153]$.

\section{Pneumothorax-Pneumomediastinum}

Air leak syndromes in the pleural cavity (i.e. pneumothorax) and/or in the mediastinum (i.e. pneumomediastinum) and/or in the subcutaneous loose tissues (i.e. sub- cutaneous emphysema) constitute very rare acute respiratory events in CTDs and may occur simultaneously or in isolation. They have been described in the literature in a variety of case reports concerning each one of the major seven CTDs, and very scarcely do they represent spontaneous events or events at initial presentation of the disease [154-169]. Most of the times, they are secondary to a preexisting chronic lung disease such as ILD with subpleural cystic-honeycombing lesions, especially in RA, scleroderma, DM-PM, and mixed connective tissue disease; the presence of peripheral necrobiotic lung nodules in RA, cystic lung disease or lower respiratory tract infections in SLE and Sjögren's syndrome, and fibrobullous disease of the lungs in ankylosing spondylitis further increases the risk of their development and aggravates their outcome. In DM, refractory pneumomediastinum is shown to develop more frequently in patients with rapidly progressing ILD, mainly CADM. Air leak syndromes should always be considered in case a CTD patient develops new respiratory symptoms or acute deterioration of dyspnea, chest pain, or facial and neck edema. Clinical behavior ranges from self-limited disease with a favorable outcome to refractory recurrent cases of pneumomediastinum or bilateral pneumothoraces leading to severe respiratory failure and death. Treatment of air leak syndromes in CTDs is not always effective and includes oxygen therapy, chest tube insertion, pleurodesis, or surgical interventions. Optimal therapy of the underlying CTD and any complication such as infection is indispensable for the ideal management of this rare respiratory manifestation in CTDs [170-181].

\section{Acute Gastroesophageal Content Aspiration Pneumonitis}

Aspiration pneumonia may develop as an acute or subacute respiratory event in any CTD patients, especially in older and debilitated ones [24, 182, 183]. However, scleroderma and DM-PM significantly surpass the other CTDs concerning this complication, due to the fact that both diseases are characterized by pathophysiologic mechanisms seriously predisposing to impaired function of swallowing and thus to overt acute aspiration or occult chronic microaspiration of oropharyngeal and/or gastropharyngeal contents $[143,184]$. In scleroderma, the gastrointestinal tract is the internal system most commonly involved. Excessive and progressive fibrosis of the entire organ, starting from the pharyngoesophageal muscles, leads to dysmotility, dysphagia, and gastroesophageal re- 
flux in the majority of patients, as well as to small intestinal bacterial overgrowth and chronic intestinal pseudoobstruction $[185,186]$. Poor oral hygiene, tooth loss, decreased saliva production, and periodontal disease are also frequently encountered in scleroderma patients, further aggravating the risk of aspiration pneumonia [187]. In DM-PM, on the other hand, dysphagia seems to be mostly related to impaired muscle contraction, reduced hyoid-laryngeal excursion, and/or failed upper esophageal sphincter relaxation $[19,143,188]$.

Aspiration of oropharyngeal and/or gastropharyngeal contents may cause airway obstruction, lung abscess, lipoid pneumonia, ILD, and diffuse aspiration bronchiolitis, but much more frequently aspiration pneumonia, an acute infectious process related to the aspiration of material contaminated by common pathogens. More rarely, aspiration of sterile regurgitated acidic gastric material occurs, leading to a chemical pneumonitis known as the Mendelson syndrome. In this case, a severe inflammatory response results in acute lung injury or even ARDS, whereas a bacterial infection may be superimposed later on. Any aspiration event may easily become aggravated in any CTD patient due to the concurrent immunological dysfunction related to both the disease and its immunosuppressive treatment. Aspiration pneumonia should always be considered in CTD patients presenting with cough, wheezing, dyspnea, weight loss, and new pulmonary infiltrates. Appropriate antimicrobials and supportive measures should be initiated as soon as possible; in addition, early management of risk factors such as reflux and gastrointestinal tract dysmotility should always be adopted in a timely manner, since the development of aspiration pneumonia in CTD patients is a dramatic acute respiratory event often leading to increased rates of morbidity and mortality especially in scleroderma and DMPM patients $[182,183,189]$.

\section{Acute Heart-Related Respiratory Events}

Cardiovascular disease is increased in CTD patients compared to the general population and significantly contributes to morbidity and mortality [190, 191]. It may present as involvement of the coronary arteries (acute coronary syndromes and ischemic heart disease), myocardium (myocarditis, cardiomyopathy, rhythm and conduction disturbances, and heart failure), endocardium (valvular heart disease and thrombi), pericardium (pericarditis and pericardial effusion), and major vessels (aneurysm formation and arterial and venous thrombo-

Acute Respiratory Events in Connective

Tissue Disorders sis) [190]. Atherosclerosis appears to be a major pathogenetic mechanism in all major CTDs, which can be as accelerated, diffuse, and extensive as in patients with diabetes mellitus. The cardinal risk cofactor in all CTDs is chronic inflammation related to autoimmunity, which adversely interacts with genetic factors, smoking habit, age, gender, obesity, diabetes mellitus, dyslipidemia, and hypertension [192, 193]. Nonatherosclerotic mechanisms such as microvascular dysfunction, cardiac autonomic neuropathy, arrhythmias, and pericardial inflammation have also a contributing role in the development of cardiovascular disease. Ischemic heart disease with myocardial infarction occurs mainly in RA and SLE, whereas pericarditis presents in SLE, microvascular perfusion abnormalities of the myocardium are found in scleroderma, and valvular heart disease and conduction abnormalities occur more often in ankylosing spondylitis [194-198].

Whereas the majority of cardiovascular events are managed in a cardiology department setting, pulmonologists often diagnose and face acute events related to effusive pericarditis with or without tamponade and pleural effusion. Pericardial involvement may occur in as much as $50 \%$ of patients with scleroderma and SLE. However, with the exception of lupus, pericarditis usually presents as a 'bystander', and the occurrence of tamponade is rare. The pathogenesis of lupus-associated pericardial effusion may be related to the deposition of immune complexes and complement activation, leading to pericardial inflammation and effusion [199-201]. Depending on the speed of fluid accumulation, pericarditis may be asymptomatic or present as a life-threatening cardiac tamponade. Classic signs of tamponade include tachycardia, neck vein distension, elevated jugular venous pressure, diminished heart sounds, pulsus paradoxus, and dyspneatachypnea [202]. Early treatment of cardiac tamponade is of paramount importance as any delay may be life-threatening. Echocardiography should be performed in all patients with suspected pericardial effusion. It allows the estimation of effusion size and hemodynamic effects as well as pericardial thickening and intrapericardial adhesions. Cardiac magnetic resonance imaging should additionally be performed in cases where myocardial disease is also suspected [203]. Pericardiocentesis is important for management but may also improve diagnostic yield. When compared to surgical drainage, echocardiographyguided pericardiocentesis has been associated with lower morbidity and mortality rates, even though the placement of a pericardial drain or surgical pericardiectomy may become necessary [204]. Increased recognition of acute heart-related respiratory events leads to appropri- 
Table 2. Acute respiratory events due to drugs

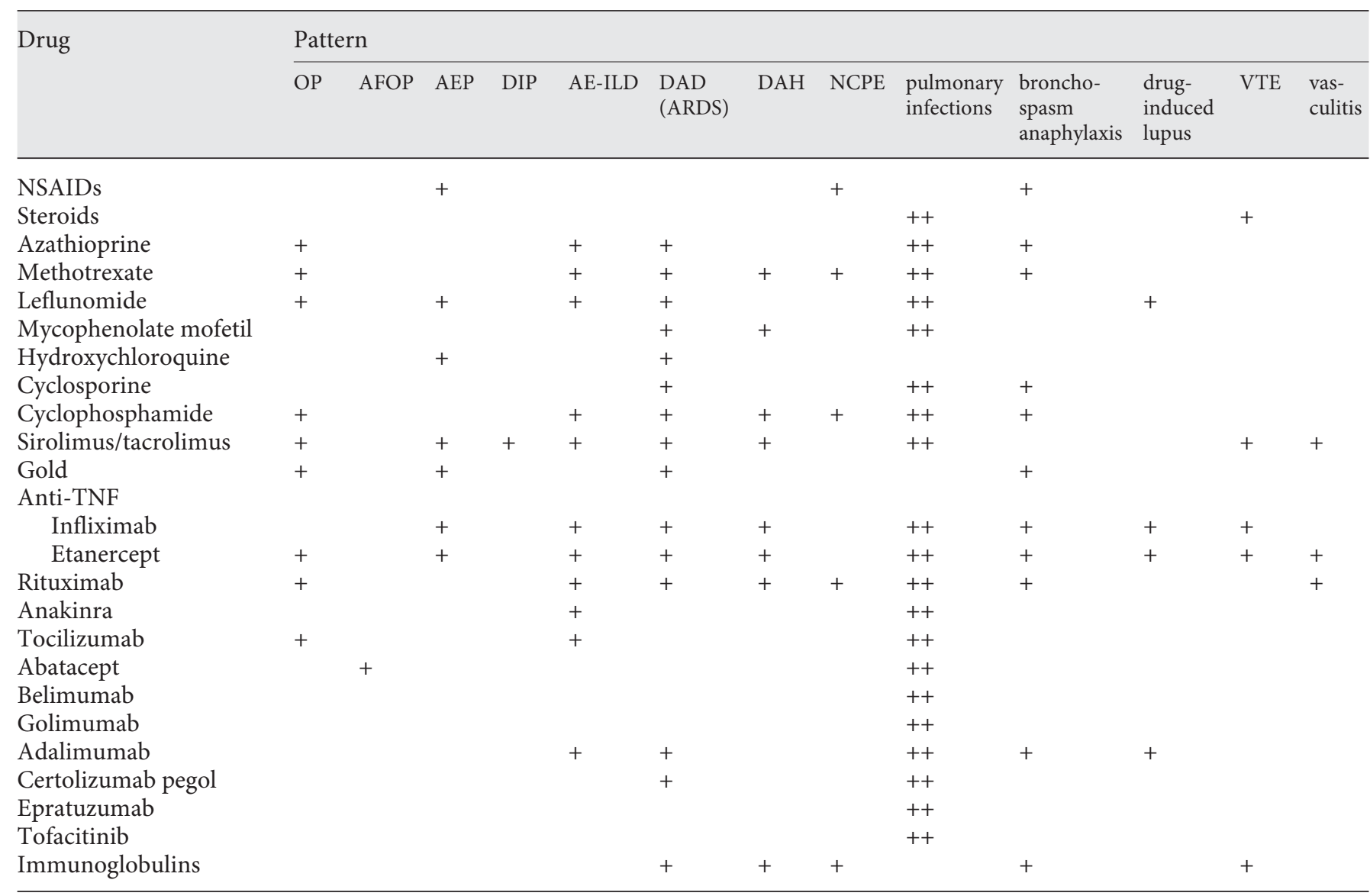

NSAIDs = Nonsteroidal anti-inflammatory drugs; AEP = acute eosinophilic pneumonia; $\mathrm{DIP}=$ desquamative interstitial pneumonia; $\mathrm{AE}-\mathrm{ILD}=$ acute exacerbation ILD; NCPE = noncardiogenic pulmonary edema; VTE = venous thromboembolism.

ate management and prevention. Appropriate management of the underlying disease with optimal control of CTD activity, specific cardiovascular treatment, and prevention of traditional risk factors may decrease the prevalence of acute heart-related respiratory events, and most importantly the associated morbidity and mortality, in CTD patients [192, 193, 205-207].

\section{Acute Antirheumatic Drug-Related Respiratory Toxicity}

Several drugs, including the most recently introduced biological factors administered in CTDs, are clearly reported to be associated with acute and often severe respiratory toxicity on their own (not related to their immunosuppressive effect), adding significantly to the 'vicious' combination of acute respiratory events related to the disease itself, superimposed infections, and acute drug-related iatrogenic respiratory disease [208]. Most if not all of the previously described acute respiratory events - and several more not reported for reasons of space - may present as an acute adverse drug effect from the lungs, adding significantly to an already complicated diagnostic approach [209]. Acute drug-induced respiratory events in CTDs usually are not due to overdose and present in largely unpredictable, severe, and often life-threatening ways [209]. Regarding acute drug-induced iatrogenic respiratory toxicity there exist several excellent reviews, statements, and book chapters, including an Internet address (www.pneumotox.com), where the reader is directed to seek advice $[210,211]$. Drugs commonly used in CTDs and the most common acute adverse events are reported in table $2[22,45,212-226]$. 


\section{Conclusions}

In CTDs, the lungs significantly contribute to morbidity and mortality, since they constitute a common site of disease involvement; a major site of infections related to the mater disease; a major site of drug-related toxicity, and a common site of treatment-related infectious complications. Avoiding lung disease might represent a major concern for future advancements in the treatment of autoimmune disorders.

\section{Acknowledgements}

The authors would like to acknowledge and sincerely thank the following persons for their contribution in providing figures: Prof. Petros Karakitsos (Department of Cytopathology, 'Attikon' University Hospital, Athens Medical School, National and Kapodistrian University of Athens, Athens, Greece), Dr. Stylianos Argentos (2nd Department of Radiology, 'Attikon' University Hospital, Athens Medical School, National and Kapodistrian University of Athens, Athens, Greece), and Dr. Dimitra Rontogianni (Department of Pathology, Evaggelismos General Hospital, Athens, Greece).

\section{References}

1 Becker MO, Riemekasten G: Risk factors for severity and manifestations in systemic sclerosis and prediction of disease course. Expert Rev Clin Immunol 2016;12:115-135.

-2 Ajeganova S, Humphreys JH, Verheul MK, van Steenbergen HW, van Nies JA, Hafström I, Svensson B, Huizinga TW, Trouw LA, Verstappen SM, van der Helm-van Mil AH: Anticitrullinated protein antibodies and rheumatoid factor are associated with increased mortality but with different causes of death in patients with rheumatoid arthritis: a longitudinal study in three European cohorts. Ann Rheum Dis 2016, Epub ahead of print.

3 Solomon JJ, Chung JH, Cosgrove GP, Demoruelle MK, Fernandez-Perez ER, Fischer A, Frankel SK, Hobbs SB, Huie TJ, Ketzer J, Mannina A, Olson AL, Russell G, Tsuchiya Y, Yunt ZX, Zelarney PT, Brown KK, Swigris JJ: Predictors of mortality in rheumatoid arthritis-associated interstitial lung disease. Eur Respir J 2016;47:588-596.

-4 Richter A, Listing J, Schneider M, Klopsch T, Kapelle A, Kaufmann J, Zink A, Strangfeld A: Impact of treatment with biologic DMARDs on the risk of sepsis or mortality after serious infection in patients with rheumatoid arthritis. Ann Rheum Dis 2015, Epub ahead of print.

5 Rees F, Doherty M, Grainge MJ, Lanyon P, Davenport G, Zhang W: Mortality in systemic lupus erythematosus in the United Kingdom 1999-2012. Rheumatology (Oxford) 2016, Epub ahead of print.

-6 Bernal-Macías S, Reyes-Beltrán B, MolanoGonzález N, Augusto Vega D, Bichernall C, Díaz LA, Rojas-Villarraga A, Anaya JM: Outcome of patients with autoimmune diseases in the intensive care unit: a mixed cluster analysis. Lupus Sci Med 2015;2:e000122.

7 Lega JC, Reynaud Q, Belot A, Fabien N, Durieu I, Cottin V: Idiopathic inflammatory myopathies and the lung. Eur Respir Rev 2015; 24:216-238.
8 Hajas A, Szodoray P, Nakken B, Gaal J, Zöld E, Laczik R, Demeter N, Nagy G, Szekanecz Z, Zeher M, Szegedi G, Bodolay E: Clinical course, prognosis, and causes of death in mixed connective tissue disease. J Rheumatol 2013;40:1134-1142.

-9 Exarchou S, Lie E, Lindström U, Askling J, Forsblad-d'Elia H, Turesson C, Kristensen LE, Jacobsson LT: Mortality in ankylosing spondylitis: results from a nationwide population-based study. Ann Rheum Dis 2015, Epub ahead of print.

10 Singh AG, Singh S, Matteson EL: Rate, risk factors and causes of mortality in patients with Sjögren's syndrome: a systematic review and meta-analysis of cohort studies. Rheumatology (Oxford) 2016;55:450-460.

-11 Geri G, Dadoun S, Bui T, Del Castillo Pinol N, Paternotte S, Dougados M, Gossec L: Risk of infections in bronchiectasis during diseasemodifying treatment and biologics for rheumatic diseases. BMC Infect Dis 2011;11:304.

12 Park IN, Kim DS, Shim TS, Lim CM, Lee SD, Koh Y, Kim WS, Kim WD, Jang SJ, Colby TV: Acute exacerbation of interstitial pneumonia other than idiopathic pulmonary fibrosis. Chest 2007;132:214-220.

-13 Kazzaz NM, Coit P, Lewis EE, McCune WJ, Sawalha AH, Knight JS: Systemic lupus erythematosus complicated by diffuse alveolar haemorrhage: risk factors, therapy and survival. Lupus Sci Med 2015;2:e000117.

14 Cervera R, Rodríguez-Pintó I; Group Espinosa on behalf of the Task Force on Catastrophic Antiphospholipid Syndrome: Catastrophic antiphospholipid syndrome: task force report summary. Lupus 2014;23:1283-1285.

-15 Tang R, Millett CR, Green JJ: Amyopathic dermatomyositis complicated by pneumomediastinum. J Clin Aesthet Dermatol 2013; 6:40-43.

16 Dalakas MC: Inflammatory muscle diseases. N Engl J Med 2015;372:1734-1747.

$17 \mathrm{Hu}$ X, Lee JS, Pianosi PT, Ryu JH: Aspirationrelated pulmonary syndromes. Chest 2015; 147:815-823.
18 Gyger G, Baron M: Gastrointestinal manifestations of scleroderma: recent progress in evaluation, pathogenesis, and management. Curr Rheumatol Rep 2012;14:22-29.

19 Ebert EC: Review article: the gastrointestinal complications of myositis. Aliment Pharmacol Ther 2010;31:359-365.

20 Miner JJ, Kim AH: Cardiac manifestations of systemic lupus erythematosus. Rheum Dis Clin North Am 2014;40:51-60.

-21 Katchamart W, Trudeau J, Phumethum V, Bombardier C: Efficacy and toxicity of methotrexate (MTX) monotherapy versus MTX combination therapy with non-biological disease-modifying antirheumatic drugs in rheumatoid arthritis: a systematic review and metaanalysis. Ann Rheum Dis 2009;68:1105-1112.

22 Roubille C, Haraoui B: Interstitial lung diseases induced or exacerbated by DMARDs and biologic agents in rheumatoid arthritis: a systematic literature review. Semin Arthritis Rheum 2014;43:613-626.

23 Dixon WG, Symmons DP, Lunt M, Watson KD, Hyrich KL; British Society for Rheumatology Biologics Register Control Centre Consortium, Silman AJ; British Society for Rheumatology Biologics Register: Serious infection following anti-tumor necrosis factor alpha therapy in patients with rheumatoid arthritis: lessons from interpreting data from observational studies. Arthritis Rheum 2007; 56:2896-2904.

24 Alarcón CS: Infections in systemic connective tissue diseases: systemic lupus erythematosus, scleroderma, and polymyositis/dermatomyositis. Infect Dis Clin North Am 2006;20:849875

25 Janssen NM, Karnad DR, Guntupalli KK: Rheumatologic diseases in the intensive care unit: epidemiology, clinical approach, management, and outcome. Crit Care Clin 2002; 18:729-748. 
-26 Tektonidou MG, Wang Z, Dasgupta A, Ward MM: Burden of serious infections in adults with systemic lupus erythematosus: a nationwide population based-study, 1996-2011. Arthritis Care Res (Hoboken) 2015;67:10781085.

-27 Galloway JB, Hyrich KL, Mercer LK, Dixon WG, Fu B, Ustianowski AP, Watson KD, Lunt M, Symmons DP; BSRBR Control Centre Consortium; British Society for Rheumatology Biologics Register: Anti-TNF therapy is associated with an increased risk of serious infections in patients with rheumatoid arthritis especially at the first 6 months of treatment: updated results from the British Society for Rheumatology Biologics Register with special emphasis on risks in the elderly. Rheumatology (Oxford) 2011;50:124-131.

28 Listing J, Strangfeld A, Kary S, Rau R, von Hinueber U, Stoyanova-Scholz M, GromnicaIhle E, Antoni C, Herzer P, Kekow J, Schnei$\operatorname{der}$ M, Zink A: Infections in patients with rheumatoid arthritis treated with biologic agents. Arthritis Rheum 2005;52:34033412.

29 Molyneaux PL, Cox MJ, Willis-Owen SA, Mallia P, Russell KE, Russell AM, Murphy E, Johnston SL, Schwartz DA, Wells AU, Cookson WO, Maher TM, Moffatt MF: The role of bacteria in the pathogenesis and progression of idiopathic pulmonary fibrosis. Am J Respir Crit Care Med 2014;190:906-913.

-30 Ding T, Ledingham J, Luqmani R, Westlake S, Hyrich K, Lunt M, Kiely P, Bukhari M, Abernethy R, Bosworth A, Ostor A, Gadsby K, McKenna F, Finney D, Dixey J, Deighton C; Standards, Audit and Guidelines Working Group of BSR Clinical Affairs Committee; BHPR: Rheumatoid arthritis guidelines on safety of anti-TNF therapies. Rheumatology (Oxford) 2010;49:2217-2219.

- 31 Lake F, Proudman S: Rheumatoid arthritis and lung disease: from mechanisms to a practical approach. Semin Respir Crit Care Med 2014;35:222-238.

32 Papiris SA, Manali ED, Kolilekas L, Kagouridis K, Triantafillidou C, Tsangaris I, Roussos C: Clinical review: idiopathic pulmonary fibrosis acute exacerbations - unravelling Ariadne's thread. Crit Care 2010;14:246.

- 33 Kondoh Y, Taniguchi H, Kawabata Y, Yokoi T, Suzuki K, Takagi K: Acute exacerbation in idiopathic pulmonary fibrosis. Analysis of clinical and pathologic findings in three cases. Chest 1993;103:1808-1812.

-34 Collard HR, Moore BB, Flaherty KR, Brown KK, Kaner RJ, King TE Jr, Lasky JA, Loyd JE, Noth I, Olman MA, Raghu G, Roman J, Ryu JH, Zisman DA, Hunninghake GW, Colby TV, Egan JJ, Hansell DM, Johkoh T, Kaminski N, Kim DS, Kondoh Y, Lynch DA, MüllerQuernheim J, Myers JL, Nicholson AG, Selman M, Toews GB, Wells AU, Martinez FJ; Idiopathic Pulmonary Fibrosis Clinical Research Network Investigators; Idiopathic Pulmonary Fibrosis Clinical Research Network Investigators: Acute exacerbations of idio- pathic pulmonary fibrosis. Am J Respir Crit Care Med 2007;176:636-643.

35 Raghu G, Collard HR, Egan JJ, Martinez FJ, Behr J, Brown KK, Colby TV, Cordier JF, Flaherty KR, Lasky JA, Lynch DA, Ryu JH, Swigris JJ, Wells AU, Ancochea J, Bouros D, Carvalho C, Costabel U, Ebina M, Hansell DM, Johkoh T, Kim DS, King TE Jr, Kondoh Y, Myers J, Müller NL, Nicholson AG, Richeldi L, Selman M, Dudden RF, Griss BS, Protzko SL, Schünemann HJ; ATS/ERS/JRS/ALAT Committee on Idiopathic Pulmonary Fibrosis: An official ATS/ERS/JRS/ALAT statement: idiopathic pulmonary fibrosis: evidence-based guidelines for diagnosis and management. Am J Respir Crit Care Med $2011 ; 183: 788-824$.

- 36 Inase N, Sawada M, Ohtani Y, Miyake S, Isogai S, Sakashita H, Miyazaki Y, Yoshizawa Y: Cyclosporin A followed by the treatment of acute exacerbation of idiopathic pulmonary fibrosis with corticosteroid. Intern Med 2003;42:565-570.

37 Sakamoto S, Homma S, Miyamoto A, Kurosaki A, Fujii T, Yoshimura K: Cyclosporin A in the treatment of acute exacerbation of idiopathic pulmonary fibrosis. Intern Med 2010;49:109-115.

38 Morawiec E, Tillie-Leblond I, Pansini V, Salleron J, Remy-Jardin M, Wallaert B: Exacerbations of idiopathic pulmonary fibrosis treated with corticosteroids and cyclophosphamide pulses. Eur Respir J 2011;38:14871489.

39 Papiris SA, Manali ED, Kolilekas L, Triantafillidou C, Tsangaris I, Kagouridis K: Steroids in idiopathic pulmonary fibrosis acute exacerbation: defenders or killers? Am J Respir Crit Care Med 2012;185:587-588.

40 Idiopathic Pulmonary Fibrosis Clinical Research Network, Raghu G, Anstrom KJ, King Jr TE, Lasky JA, Martinez FJ: Prednisone, azathioprine, and $\mathrm{N}$-acetylcysteine for pulmonary fibrosis. N Engl J Med 2012;366:19681977.

41 Papiris SA, Kagouridis K, Kolilekas L, Papaioannou AI, Roussou A, Triantafillidou C, Baou K, Malagari K, Argentos S, Kotanidou A, Karakatsani A, Manali ED: Survival in idiopathic pulmonary fibrosis acute exacerbations: the non-steroid approach. BMC Pulm Med 2015;15:162.

42 Parambil JG, Myers JL, Ryu JH: Histopathologic features and outcome of patients with acute exacerbation of idiopathic pulmonary fibrosis undergoing surgical lung biopsy. Chest 2005;128:3310-3315.

43 Tachikawa R, Tomii K, Ueda H, Nagata K, Nanjo S, Sakurai A, Otsuka K, Kaji R, Hayashi M, Katakami N, Imai Y: Clinical features and outcome of acute exacerbation of interstitial pneumonia: collagen vascular diseasesrelated versus idiopathic. Respiration 2012; 83:20-27.

44 Mori S: Management of rheumatoid arthritis patients with interstitial lung disease: safety of biological antirheumatic drugs and assess- ment of pulmonary fibrosis. Clin Med Insights Circ Respir Pulm Med 2015;9(suppl 1):41-49.

45 Curtis JR, Sarsour K, Napalkov P, Costa LA, Schulman KL: Incidence and complications of interstitial lung disease in users of tocilizumab, rituximab, abatacept and anti-tumor necrosis factor a agents, a retrospective cohort study. Arthritis Res Ther 2015;17:319.

46 Koo BS, Hong S, Kim YJ, Kim YG, Lee CK, Yoo B: Mortality in patients with rheumatoid arthritis-associated interstitial lung disease treated with an anti-tumor necrosis factor agent. Korean J Intern Med 2015;30: 104-109.

47 Naqibullah M, Shaker SB, Bach KS, Bendstrup E: Rituximab-induced interstitial lung disease: five case reports. Eur Clin Respir J 2015;2:10.3402/ecri.v2.27178.

48 Kim YJ, Song M, Ryu JC: Mechanisms underlying methotrexate-induced pulmonary toxicity. Expert Opin Drug Saf 2009;8:451-458.

49 Lateef O, Shakoor N, Balk RA: Methotrexate pulmonary toxicity. Expert Opin Drug Saf 2005;4:723-730.

50 Thompson AE, Bashook PG: Rheumatologists' recommended patient information when prescribing methotrexate for rheumatoid arthritis. Clin Exp Rheumatol 2010;28: 539-545.

51 Listing J, Gerhold K, Zink A: The risk of infections associated with rheumatoid arthritis, with its comorbidity and treatment. Rheumatology (Oxford) 2013;52:53-61.

52 Chen IJ, Tsai WP, Jan Wu YJ, Luo SF, Ho HH, Liou LB, Chen JY, Kuo CF, Chang HC, Yang $\mathrm{CH}, \mathrm{Yu} \mathrm{KH}$ : Infections in polymyositis and dermatomyositis: analysis of 192 cases. Rheumatology (Oxford) 2010;49:2429-2439.

53 Barrett O, Abramovich E, Dreiher J, Novack V, Abu-Shakra M: Mortality due to sepsis in patients with systemic lupus erythematosus and rheumatoid arthritis. Isr Med Assoc J 2014;16:634-635.

54 Petri M: Infection in systemic lupus erythematosus. Rheum Dis Clin North Am 1998;24: 423-456.

55 Salvana EMT, Salata RA: Infectious complications associated with monoclonal antibodies and related small molecules. Clin Microbiol Rev 2009;22:274-290.

- 56 Boyton RJ, Reynolds CJ, Quigley KJ, Altmann DM: Immune mechanisms and the impact of the disrupted lung microbiome in chronic bacterial lung infection and bronchiectasis. Clin Exp Immunol 2013;171:117-123.

57 Lisnevskaia L, Murphy G, Isenberg D: Systemic lupus erythematosus. Lancet 2014;384: 1878-1888.

58 Zandman-Goddard G, Shoenfeld Y: SLE and infections. Clin Rev Allergy Immunol 2003; 25:29-40.

59 Papiris SA, Manali ED, Kolilekas L, Kagouridis K, Maniati M, Borie R, Pradere P, Crestani $\mathrm{B}$, Bouros D: Investigation of lung involvement in rheumatologic disease. Respiration 2015;90:2-24. 
60 Doran MF, Crowson OS, Pond GR, O’Fallon M, Gabriel S: Frequency of infection in patients with rheumatoid arthritis compared with controls: a population-based study. Arthritis Rheum 2002;46:2287-2293.

61 Zimmermann AF, Pizzichini MM: Update on etiopathogenesis of systemic sclerosis (in English, Portuguese). Rev Bras Reumatol 2013;53:516-524.

62 Morris A, Gibson K, Collman RG: The lung microbiome in idiopathic pulmonary fibrosis. What does it mean and what should we do about it? Am J Respir Crit Care Med 2014;190: 850-852.

63 Sparks JA, Costenbader KH: Genetics, environment, and gene-environment interactions in the development of systemic rheumatic diseases. Rheum Dis Clin North Am 2014;40: 637-657.

64 Scher JU, Littman DR, Abramson SB: Review: microbiome in inflammatory arthritis and human rheumatic diseases. Arthritis Rheumatol 2016;68:35-45.

65 Haraoui B, Jovaisas A, Bensen WG, Faraawi R, Kelsall J, Dixit S, Rodrigues J, Sheriff M, Rampakakis E, Sampalis JS, Lehnan AJ, Otawa S, Nantel F, Shawi M: Use of corticosteroids in patients with rheumatoid arthritis treated with infliximab: treatment implications based on a real-world Canadian population. RMD Open 2015;1:e000078.

-66 Tesfa D, Ajeganova S, Hägglund H, Sander B, Fadeel B, Hafström I, Palmblad J: Late-onset neutropenia following rituximab therapy in rheumatic diseases: association with B lymphocyte depletion and infections. Arthritis Rheum 2011;63:2209-2214.

-67 Payet S, Soubrier M, Perrodeau E, Bardin T, Cantagrel A, Combe B, Dougados M, Flipo RM, Le Loët X, Shaeverbeke T, Ravaud P, Gottenberg JE, Mariette X: Efficacy and safety of rituximab in elderly patients with rheumatoid arthritis enrolled in a French Society of Rheumatology registry. Arthritis Care Res (Hoboken) 2014;66:1289-1295.

68 Westra J, van Assen S, Wilting KR, Land J, Horst G, de Haan A, Bijl M: Rituximab impairs immunoglobulin (Ig)M and IgG (subclass) responses after influenza vaccination in rheumatoid arthritis patients. Clin Exp Immunol 2014;178:40-47.

69 Wendler J, Burmester GR, Sörensen H, Krause A, Richter C, Tony HP, Rubbert-Roth A, Bartz-Bazzanella P, Wassenberg S, Haug-Rost I, Dörner T: Rituximab in patients with rheumatoid arthritis in routine practice (GERINIS): six-year results from a prospective, multicentre, non-interventional study in 2,484 patients. Arthritis Res Ther 2014;16:R80.

70 Cobo-Ibáñez T, Descalzo MÁ, Loza-Santamaría E, Carmona L, Muñoz-Fernández S: Serious infections in patients with rheumatoid arthritis and other immune-mediated connective tissue diseases exposed to anti-TNF or rituximab: data from the Spanish registry BIOBADASER 2.0. Rheumatol Int 2014;34 953-961.
71 Johnston SS, Turpcu A, Shi N, Fowler R, Chu $\mathrm{BC}$, Alexander K: Risk of infections in rheumatoid arthritis patients switching from antiTNF agents to rituximab, abatacept, or another anti-TNF agent, a retrospective administrative claims analysis. Semin Arthritis Rheum 2013;43:39-47.

-72 Bélard E, Semb S, Ruhwald M, Werlinrud AM, Soborg B, Jensen FK, Thomsen H, Brylov A, Hetland ML, Nordgaard-Lassen I, Ravn P: Prednisolone treatment affects the performance of the QuantiFERON gold in-tube test and the tuberculin skin test in patients with autoimmune disorders screened for latent tuberculosis infection. Inflamm Bowel Dis 2011;17:2340-2349.

73 Lu MC, Lai CL, Tsai CC, Koo M, Lai N: Increased risk of pulmonary and extra-pulmonary tuberculosis in patients with rheumatic diseases. Int J Tuberc Lung Dis 2015;19:15001506.

74 Cantini F, Nannini C, Niccoli L, Iannone F, Delogu G, Garlaschi G, Sanduzzi A, Matucci A, Prignano F, Conversano M, Goletti D; SAFEBIO (Italian Multidisciplinary Task Force for Screening of Tuberculosis before and during Biologic Therapy): Guidance for the management of patients with latent tuberculosis infection requiring biologic therapy in rheumatology and dermatology clinical practice. Autoimmun Rev 2015;14:503-509.

75 Iannone F, Cantini F, Lapadula G: Diagnosis of latent tuberculosis and prevention of reactivation in rheumatic patients receiving biologic therapy: international recommendations. J Rheumatol Suppl 2014;91:41-46.

-76 Bühler S, Eperon G, Ribi C, Kyburz D, van Gompel F, Visser LG, Siegrist CA, Hatz C: Vaccination recommendations for adult patients with autoimmune inflammatory rheumatic diseases. Swiss Med Wkly 2015; 145:w14159.

77 Askling J, Fored CM, Brandt L, Baecklund E, Bertilsson L, Feltelius N, Cöster L, Geborek P, Jacobsson LT, Lindblad S, Lysholm J, Rantapää-Dahlqvist S, Saxne T, van Vollenhoven RF, Klareskog L: Time-dependent increase in risk of hospitalization with infection among Swedish RA patients treated with TNF antagonists. Ann Rheum Dis 2007;66:1339-1344.

-78 Bongartz T, Sutton AJ, Sweeting MI, Buchan I, Matteson EL, Montori V: Anti-TNF antibody therapy in rheumatoid arthritis and the risk of serious infections and malignancies: systematic review and meta-analysis of rare harmful effects in randomized controlled trials. JAMA 2006;295:2275-2285.

79 Mori S, Sugimoto M: Pneumocystis jirovecii pneumonia in rheumatoid arthritis patients: risks and prophylaxis recommendations. Clin Med Insights Circ Respir Pulm Med 2015;9: 29-40.

80 Marie I, Hachulla E, Chérin P, Hellot MF, Herson S, Levesque H, Hatron PY: Opportunistic infections in polymyositis and dermatomyositis. Arthritis Rheum 2005;53:155165.
81 Krause ML, Cartin-Ceba R, Specks U, Peikert T: Update on diffuse alveolar hemorrhage and pulmonary vasculitis. Immunol Allergy Clin North Am 2012;32:587-600.

82 Lara AR, Schwarz MI: Diffuse alveolar hemorrhage. Chest 2010;137:1164-1171.

83 Fishbein GA, Fishbein MC: Lung vasculitis and alveolar hemorrhage: pathology. Semin Respir Crit Care Med 2011;32:254-263.

-84 Papiris SA, Manali ED, Kalomenidis I, Kapotsis GE, Karakatsani A, Roussos C: Bench-tobedside review: pulmonary-renal syndromes an update for the intensivist. Crit Care 2007; 11:213.

85 Cordier JF, Cottin V: Alveolar hemorrhage in vasculitis: primary and secondary. Semin Respir Crit Care Med 2011;32:310-321.

86 Andrade C, Mendonça T, Farinha F, Correia J, Marinho A, Almeida I, Vasconcelos C: Alveolar hemorrhage in systemic lupus erythematosus: a cohort review. Lupus 2016;25:7580.

87 Ednalino C, Yip J, Carsons SE: Systematic review of diffuse alveolar hemorrhage in systemic lupus erythematosus: focus on outcome and therapy. J Clin Rheumatol 2015;21:305310

88 Esper RC, Estrada IE, de la Torre León T, Gutiérrez AO, López JA: Treatment of diffuse alveolar hemorrhage secondary to lupus erythematosus with recombinant activated factor VII administered with a jet nebulizer. J Intensive Care 2014;2:47.

89 Tse JR, Schwab KE, McMahon M, Simon W: Rituximab: an emerging treatment for recurrent diffuse alveolar hemorrhage in systemic lupus erythematosus. Lupus 2015;24:756759.

90 Pacheco Claudio C, Charbonney E, Durand M, Kolan C, Laskine M: Extracorporeal membrane oxygenation in diffuse alveolar hemorrhage secondary to systemic lupus erythematosus. J Clin Med Res 2014;6:145-148.

-91 Al Rashidi A, Alajmi M, Hegazi MO: Mycophenolate mofetil as a maintenance therapy for lupus-related diffuse alveolar hemorrhage: a case report. Lupus 2011;20:15511553.

92 Gonzalez-Echavarri C, Pernas B, Ugarte A, Ruiz-Irastorza G: Severe multiorganic flare of systemic lupus erythematosus successfully treated with rituximab and cyclophosphamide avoiding high doses of prednisone. Lupus 2014;23:323-326.

93 Tagawa Y, Saito T, Takada K, Kawahata K, Kohsaka H: Successful treatment of severe refractory lupus hepatitis with mycophenolate mofetil. Lupus 2016, Epub ahead of print.

94 Tsang-A-Sjoe M, Bultink I: Systemic lupus erythematosus: review of synthetic drugs. Expert Opin Pharmacother 2015;16:27932806.

95 Zöller B, Li X, Sundquist J, Sundquist K: Risk of pulmonary embolism in patients with autoimmune disorders: a nationwide follow-up study from Sweden. Lancet 2012;379:244249. 
96 Konstantinides SV, Torbicki A, Agnelli G, Danchin N, Fitzmaurice D, Galiè N, Gibbs JS, Huisman MV, Humbert M, Kucher N, Lang I, Lankeit M, Lekakis J, Maack C, Mayer E, Meneveau N, Perrier A, Pruszczyk P, Rasmussen LH, Schindler TH, Svitil P, Vonk Noordegraaf A, Zamorano JL, Zompatori M; Task Force for the Diagnosis and Management of Acute Pulmonary Embolism of the European Society of Cardiology (ESC): 2014 ESC guidelines on the diagnosis and management of acute pulmonary embolism. Eur Heart J 2014;35:3033-3069, 3069a3069k.

-97 Ruiz-Irastorza G, Crowther M, Branch W, Khamashta MA: Antiphospholipid syndrome. Lancet 2010;376:1498-1509.

$\$ 98$ Keeling D, Mackie I, Moore GW, Greer IA, Greaves M; British Committee for Standards in Haematology: Guidelines on the investigation and management of antiphospholipid syndrome. Br J Haematol 2012;157:4758.

-99 Cervera R, Serrano R, Pons-Estel GJ, Ceberio-Hualde L, Shoenfeld Y, de Ramón E, Buonaiuto V, Jacobsen S, Zeher MM, Tarr T, Tincani A, Taglietti M, Theodossiades G, Nomikou E, Galeazzi M, Bellisai F, Meroni PL, Derksen RH, de Groot PG, Baleva M, Mosca M, Bombardieri S, Houssiau F, Gris JC, Quéré I, Hachulla E, Vasconcelos C, Fernández-Nebro A, Haro M, Amoura Z, Miyara M, Tektonidou M, Espinosa G, Bertolaccini ML, Khamashta MA; EuroPhospholipid Project Group (European Forum on Antiphospholipid Antibodies): Morbidity and mortality in the antiphospholipid syndrome during a 10-year period: a multicentre prospective study of 1,000 patients. Ann Rheum Dis 2015;74: 1011-1018.

100 Miyakis S, Lockshin MD, Atsumi T, Branch DW, Brey RL, Cervera R, Derksen RH, de Groot PG, Koike T, Meroni PL, Reber G, Shoenfeld Y, Tincani A, Vlachoyiannopoulos PG, Krilis SA: International consensus statement on an update of the classification criteria for definite antiphospholipid syndrome (APS). J Thromb Haemost 2006;4: 295-306.

101 Gupta T, Khera S, Kolte D, Aronow WS, Singh T, Pinnamaneni S, Fallon JT, Frishman WH, Gass A: Back from the brink: catastrophic antiphospholipid syndrome. Am J Med 2015;128:574-577.

102 Vieregge GB, Harrington TJ, Andrews DM, Carpintero MF, Green DF, Nayer A: Catastrophic antiphospholipid syndrome with severe acute thrombotic microangiopathy and hemorrhagic complications. Case Rep Med 2013;2013:915309.

103 Routy B, Huynh T, Fraser R, Séguin C: Vascular endothelial cell function in catastrophic antiphospholipid syndrome: a case report and review of the literature. Case Rep Hematol 2013;2013:710365.
104 Ortega-Hernandez OD, Agmon-Levin N, Blank M, Asherson RA, Shoenfeld Y: The physiopathology of the catastrophic antiphospholipid (Asherson's) syndrome: compelling evidence. J Autoimmun 2009;32:1-6.

105 Cervera R, Bucciarelli S, Plasín MA, GómezPuerta JA, Plaza J, Pons-Estel G, Shoenfeld Y, Ingelmo M, Espinos G; Catastrophic Antiphospholipid Syndrome (CAPS) Registry Project Group (European Forum on Antiphospholipid Antibodies): Catastrophic antiphospholipid syndrome (CAPS): descriptive analysis of a series of 280 patients from the 'CAPS Registry'. J Autoimmun 2009;32:240-245.

-106 Praprotnik S, Ferluga D, Vizjak A, Hvala A, Avčin T, Rozman B: Microthrombotic/ microangiopathic manifestations of the antiphospholipid syndrome. Clin Rev Allergy Immunol 2009;36:109-125.

107 Garcia-Carrasco M, Mendoza-Pinto C, Macias-Diaz S, Vazquez de Lara F, EtchegarayMorales I, Galvez-Romero JL, Mendez-Martinez S, Cervera R: The role of infectious diseases in the catastrophic antiphospholipid syndrome. Autoimmun Rev 2015;14:10661071.

108 Hanouna G, Morel N, Le Thi Huong D, Josselin L, Vauthier-Brouzes D, Saadoun D, Kettaneh A, Levesque K, Le Guern V, Goffinet F, Carbonne B, Amoura Z, Piette JC, Nizard J, Costedoat-Chalumeau N: Catastrophic antiphospholipid syndrome and pregnancy: an experience of 13 cases. Rheumatology (Oxford) 2013;52:1635-1641.

-109 Wiedermann FJ, Lederer W, Sepp N, Schobersberger W: ARDS in catastrophic antiphospholipid syndrome. Lupus 2001;10: 382-383.

110 Cartin-Ceba R, Peikert T, Ashrani A, Keogh K, Wylam ME, Ytterberg S, Specks U: Primary antiphospholipid syndrome-associated diffuse alveolar hemorrhage. Arthritis Care Res (Hoboken) 2014;66:301-310.

111 Lim W: Antiphospholipid syndrome. Hematology Am Soc Hematol Educ Program 2013;2013:675-680.

112 Cervera R, Espinosa G: Update on the catastrophic antiphospholipid syndrome and the 'CAPS Registry'. Semin Thromb Hemost 2012;38:333-338.

113 Gerosa M, Meroni PL, Erkan D: Recognition and management of antiphospholipid syndrome. Curr Opin Rheumatol 2016;28:5159.

114 Katzenstein AL: Acute lung injury patterns: diffuse alveolar damage and bronchiolitis obliterans-organizing pneumonia; in Katzenstein AL, Askin FB, Livolsi VA (eds): Katzenstein and Askin's Surgical Pathology of Non-Neoplastic Lung Disease, ed 3. Philadelphia, WB Saunders, 1997, pp 14-47.
115 American Thoracic Society; European Respiratory Society: American Thoracic Society/European Respiratory Society International Multidisciplinary Consensus Classification of the Idiopathic Interstitial Pneumonias. This joint statement of the American Thoracic Society (ATS), and the European Respiratory Society (ERS) was adopted by the ATS board of directors, June 2001 and by the ERS Executive Committee, June 2001. Am J Respir Crit Care Med 2002; 165:277-304.

116 Travis WD, Costabel U, Hansell DM, King TE Jr, Lynch DA, Nicholson AG, Ryerson CJ, Ryu JH, Selman M, Wells AU, Behr J, Bouros D, Brown KK, Colby TV, Collard HR, Cordeiro CR, Cottin V, Crestani B, Drent M, Dudden RF, Egan J, Flaherty K, Hogaboam C, Inoue Y, Johkoh T, Kim DS, Kitaichi M, Loyd J, Martinez FJ, Myers J, Protzko S, Raghu G, Richeldi L, Sverzellati N, Swigris J, Valeyre D; ATS/ERS Committee on Idiopathic Interstitial Pneumonias: An official American Thoracic Society/European Respiratory Society statement: update of the international multidisciplinary classification of the idiopathic interstitial pneumonias. Am I Respir Crit Care Med 2013;188:733-748.

117 Lazor R: Organizing pneumonias; in Cottin V, et al (eds): Orphan Lung Diseases: A Clinical Guide to Rare Lung Disease. London, Springer, 2015, pp 363-378.

118 Cordier JF: Cryptogenic organising pneumonia. Eur Respir J 2006;28:422-446.

-119 Beasley MB, Franks TJ, Galvin JR, Gochuico B, Travis WD: Acute fibrinous and organizing pneumonia: a histological pattern of lung injury and possible variant of diffuse alveolar damage. Arch Pathol Lab Med 2002; 126:1064-1070.

120 Beasley MB: The pathologist's approach to acute lung injury. Arch Pathol Lab Med 2010;134:719-727.

121 Yoo JW, Song JW, Jang SJ, Lee CK, Kim MY, Lee HK, Jegal Y, Kim DS: Comparison between cryptogenic organizing pneumonia and connective tissue disease-related organizing pneumonia. Rheumatology (Oxford) 2011;50:932-938.

122 Kligerman SJ, Franks TJ, Galvin JR: Organization and fibrosis as a response to lung injury in diffuse alveolar damage, organizing pneumonia, and acute fibrinous and organizing pneumonia. Radiographics 2013;33: 1951-1975.

23 Rojas CML, Borella E, Palma L, Ragozzino S, De Ramón E, Gomez-Huelgas R, Punzi L, Doria A: Bronchiolitis obliterans organizing pneumonia in patients with autoimmune rheumatic diseases. Immunol Res 2015;61: 97-103.

124 Henriet AC, Diot E, Marchand-Adam S, de Muret A, Favelle O, Crestani B, Diot P: Organizing pneumonia can be the inaugural manifestation in connective tissue diseases, including Sjögren's syndrome. Eur Respir Rev 2010;19:161-163. 
-125 Tsuchiya Y, Fischer A, Solomon JJ, Lynch DA: Connective tissue disease-related thoracic disease. Clin Chest Med 2015;36:283-297.

-126 Yousem SA, Colby TV, Carrington CB: Lung biopsy in rheumatoid arthritis. Am Rev Respir Dis 1985;131:770-777.

-127 Hakala M, Pääkkö P, Huhti E, Tarkka M, Sutinen S: Open lung biopsy of patients with rheumatoid arthritis. Clin Rheumatol 1990; 9:452-460.

128 Koreeda Y, Higashimoto I, Yamamoto M, Takahashi M, Kaji K, Fujimoto M, Kuwana M, Fukuda Y: Clinical and pathological findings of interstitial lung disease patients with anti-aminoacyl-tRNA synthetase autoantibodies. Intern Med 2010;49:361-369.

-129 Lega JC, Reynaud Q, Belot A, Fabien N, Durieu I, Cottin V: Idiopathic inflammatory myopathies and the lung. Eur Respir Rev 2015;24:216-238.

-130 Connors GR, Christopher-Stine L, Oddis CV, Danoff SK: Interstitial lung disease associated with the idiopathic inflammatory myopathies: what progress has been made in the past 35 years? Chest 2010;138:14641474.

131 Mukae H, Ishimoto H, Sakamoto N, Hara S, Kakugawa T, Nakayama S, Ishimatsu Y, Kawakami A, Eguchi K, Kohno S: Clinical differences between interstitial lung disease associated with clinically amyopathic dermatomyositis and classic dermatomyositis. Chest 2009;136:1341-1347.

132 Tillie-Leblond I, Wislez M, Valeyre D, Crestani B, Rabbat A, Israel-Biet D, Humbert M, Couderc LJ, Wallaert B, Cadranel J: Interstitial lung disease and anti-Jo-1 antibodies: difference between acute and gradual onset. Thorax 2008;63:53-59.

133 Prahalad S, Bohnsack JF, Maloney CG, Leslie KO: Fatal acute fibrinous and organizing pneumonia in a child with juvenile dermatomyositis. J Pediatr 2005;146:289-292.

134 Valim V, Rocha RH, Couto RB, Paixão TS, Serrano EV: Acute fibrinous and organizing pneumonia and undifferentiated connective tissue disease: a case report. Case Rep Rheumatol 2012;2012:549298.

135 Hariri LP, Unizony S, Stone J, Mino-Kenudson M, Sharma A, Matsubara O, Mark EJ: Acute fibrinous and organizing pneumonia in systemic lupus erythematosus: a case report and review of the literature. Pathol Int 2010;60:755-759.

136 Sauter JL, Butnor KJ: Expanding the spectrum of pulmonary histopathological manifestations of anti-synthetase syndrome: antiEJ-associated acute fibrinous and organizing pneumonia. Histopathology 2014;65:581582.

-137 Selva-O’Callaghan A, Labrador-Horrillo M, Muñoz-Gall X, Martínez-Gomez X, MajóMasferrer J, Solans-Laque R, Simeon-Aznar CP, Morell-Brotard F, Vilardell-Tarrés M: Polymyositis/dermatomyositis-associated lung disease: analysis of a series of $81 \mathrm{pa}-$ tients. Lupus 2005;14:534-542.
138 Schiavi EA, Roncoroni AJ, Puy RJ: Isolated bilateral diaphragmatic paresis with interstitial lung disease. An unusual presentation of dermatomyositis. Am Rev Respir Dis 1984; 129:337-339.

139 Nozaki Y, Ikoma S, Funauchi M, Kinoshita $\mathrm{K}$ : Respiratory muscle weakness with dermatomyositis during pregnancy: successful treatment with intravenous immunoglobulin therapy. J Rheumatol 2008;35:2289.

140 Astudillo LM, Carreiro M, Sailler L, Dingremont CF, Arlet PM: Hypercapnic coma due to diaphragmatic involvement in a patient with dermatomyositis. Clin Exp Rheumatol 2001;19:456-458.

141 Papiris SA, Dalakas MC, Moutsopoulos HM: Respiratory muscle involvement in systemic autoimmune diseases; in Roussos $\mathrm{C}$ (ed): The Thorax (Lung Biology in Health and Disease), ed 2, rev, exp. New York, Marcel Dekker, 1995, pp 2245-2257.

142 Martin L, Chalmers IM, Dhingra S, McCarthy D, Hunter T: Measurements of maximum respiratory pressures in polymyositis and dermatomyositis. J Rheumatol 1985;12:104-107.

143 Langdon PC, Mulcahy K, Shepherd KL, Low VH, Mastaglia F: Pharyngeal dysphagia in inflammatory muscle diseases resulting from impaired suprahyoid musculature. Dysphagia 2012;27:408-417.

144 Warrington KJ, Moder KG, Brutinel WM: The shrinking lungs syndrome in systemic lupus erythematosus. Mayo Clin Proc 2000; 75:467-472.

145 Jakati S, Rajasekhar L, Uppin M, Challa S: SLE myopathy: a clinicopathological study. Int J Rheum Dis 2015;18:886-891.

- 146 Pillai S, Mehta J, Levin T, Muzumdar H, Nandalike K: Shrinking lung syndrome presenting as an initial pulmonary manifestation of SLE. Lupus 2014;23:1201-1203.

147 Pérez-de-Llano LA, Castro-Añón O, López MJ, Escalona E, Teijeira S, Sánchez-Andrade A: Shrinking lung syndrome caused by lupus myopathy. QJM 2011;104:259-262.

148 Allen D, Stoller JK, Minai O: A 45-year-old woman with systemic lupus erythematosus and progressive dyspnea. Chest 2007;131: 1252-1255.

149 Carmier D, Diot E, Diot P: Shrinking lung syndrome: recognition, pathophysiology and therapeutic strategy. Expert Rev Respir Med 2011;5:33-39.

150 Hardy K, Herry I, Attali V, Cadranel J, Similowski T: Bilateral phrenic paralysis in a patient with systemic lupus erythematosus. Chest 2001;119:1274-1277.

151 Hawkins P, Davison AG, Dasgupta B, Moxham J: Diaphragm strength in acute systemic lupus erythematosus in a patient with paradoxical abdominal motion and reduced lung volumes. Thorax 2001;56:329-330.

152 Worth H, Grahn S, Lakomek HJ, Bremer G, Goeckenjan G: Lung function disturbances versus respiratory muscle fatigue in patients with systemic lupus erythematosus. Respiration 1988;53:81-90.
153 Peñacoba Toribio P, Córica Albani ME, Mayos Pérez M, Rodríguez de la Serna A: Rituximab in the treatment of shrinking lung syndrome in systemic lupus erythematosus. Rheumatol Clin 2014; 10:325-327.

154 Adelowo O, Akintayo RO, Olaosebikan H, Oba R: Recurrent spontaneous subcutaneous emphysema in a patient with rheumatoid arthritis. BMJ Case Rep 2015; 2015:bcr2015210802.

155 Komarla A, Yu GH, Shahane A: Pleural effusion, pneumothorax, and lung entrapment in rheumatoid arthritis. J Clin Rheumatol 2015;21:211-215.

156 Saravana S, Gillott T, Abourawi F, Peters M, Campbell A, Griffith S: Spontaneous pneumothorax: an unusual presentation of rheumatoid arthritis. Rheumatology (Oxford) 2003;42:1415-1416.

157 Bhardwaj H, Bhardwaj B, Carlile PV: Recurrent pneumomediastinum in a patient with rheumatoid arthritis. Monaldi Arch Chest Dis 2013;79:136-139.

158 Zhang L, Shen M, Zhang F, Tang F: Survival analysis and risk factors for mortality in connective tissue disease-associated pneumomediastinum. Rheumatol Int 2014;34:16571663.

159 Ahmed AH, Awouda EA: Spontaneous pneumomediastinum and subcutaneous emphysema in systemic lupus erythematosus.BMJCaseRep2010;2010:bcr0220102765.

160 Paira SO, Roverano S: Bilateral pneumothorax and mediastinal emphysema in systemic lupus erythematosus. Clin Rheumatol 1992; 11:571-573.

161 Masuda A, Tsushima T, Shizume K, Mochizuki T, Isono $\mathrm{K}$, Demura $\mathrm{H}$, Miyasaka $\mathrm{N}$, Nishioka K: Recurrent pneumothoraces and mediastinal emphysema in systemic lupus erythematosus. J Rheumatol 1990;17:544548.

162 Maeda R, Isowa N, Miura H, Tokuyasu H: Systemic lupus erythematosus with multiple lung cysts. Interact Cardiovasc Thorac Surg 2009;8:701-702.

163 Yen JH, Tsai WC, Ou TT, Lin SC, Chen CJ, Liu HW: Systemic lupus erythematosus complicated by recurrent spontaneous pneumothorax - a case report. Kaohsiung J Med Sci 2001;17:540-544.

164 Watanabe S, Tambo Y, Waseda Y, Nishimura O, Murakami S, Tsujibata A, Fujimura M: Pneumothorax as a first manifestation of SS. Rheumatology (Oxford) 2012;51:13341336.

165 Yoon J, Finger DR, Pina JS: Spontaneous pneumothorax in scleroderma. J Clin Rheumatol 2004;10:207-209.

166 Zeuner M, Müller-Ladner U, Mohr VD, Lang B: Spontaneous pneumothorax in a patient with systemic sclerosis. Clin Rheumatol 1996;15:211-213.

167 Ng SC, Tan WC: Bilateral spontaneous pneumothorax in systemic sclerosis - report of two cases. J Rheumatol 1990;17:689-691. 
168 Haroon M, McLaughlin P, Henry M, Harney S: Spontaneous pneumomediastinum in a patient with anti-centromere antibodypositive limited scleroderma. J Clin Rheumatol 2011;17:42-43.

169 Mohammad A, Boon Low T, O’Dwyer D, McElvaney G, Kearns G: Spontaneous pneumo-mediastinum in systemic sclerosis - a case report. Rheumatology (Oxford) 2007; 46:1376-1377.

170 Teixeira Moreira Almeida Mdo S, Dias LT, Fernandes SJ, Almeida JV: Spontaneous pneumomediastinum and subcutaneous emphysema in systemic sclerosis. Rheumatol Int 2007;27:675-677.

171 Bradley JD: Spontaneous pneumomediastinum in adult dermatomyositis. Ann Rheum Dis 1986;45:780-782.

172 Gürün Kaya A, Çiledağ A, Küçükşahin O, Özdemir Kumbasar Ö, Atasoy Ç: A case of amyopathic dermatomyositis with pneumomediastinum and subcutaneous emphysema. Case Rep Rheumatol 2015;2015:813902.

173 Ma X, Chen Z, Hu W, Guo Z, Wang Y, Kuwana $M$, Sun L: Clinical and serological features of patients with dermatomyositis complicated by spontaneous pneumomediastinum. Clin Rheumatol 2016;35:489-493.

174 Alexander J, Packham S, Warwick G, Mohan Das L: Spontaneous pneumomediastinum: an unusual but serious complication of dermatomyositis. BMJ Case Rep 2014; 2014:bcr2014206787.

175 Tang R, Millett CR, Green JJ: Amyopathic dermatomyositis complicated by pneumomediastinum. J Clin Aesthet Dermatol 2013; 6:40-43.

176 Jansen TL, Barrera P, van Engelen BG, Cox N, Laan RF, van de Putte LB: Dermatomyositis with subclinical myositis and spontaneous pneumomediastinum with pneumothorax: case report and review of the literature. Clin Exp Rheumatol 1998;16:733-735.

-177 McBrien C, Penketh A, Johnson H, Nicholson AG, Wells A: Recurrent pneumothoraces in a 17-year-old man with mixed connective tissue disease. Thorax 2014;69:685-686.

178 Ismael S, Wermert D, Dang-Tran KD, Venot M, Fagon JY, Diehl JL: Severe excessive dynamic airway collapse in a patient with primary Sjögren's syndrome. Respir Care 2014; 59:e156-e159.

179 Ersoy E, Akgol G, Ozgocmen S: Bilateral spontaneous pneumothorax in a patient with longstanding ankylosing spondylitis. Acta Reumatol Port 2014;39:353-354.

180 Kaneda H, Saito Y, Okamoto M, Maniwa T, Minami K, Imamura H: Bilaterally repeated spontaneous pneumothorax with ankylosing spondylitis. Gen Thorac Cardiovasc Surg 2007;55:266-269.

-181 Lee CC, Lee SH, Chang IJ, Lu TC, Yuan A, Chang TA, Tsai KC, Chen WJ: Spontaneous pneumothorax associated with ankylosing spondylitis. Rheumatology (Oxford) 2005; 44:1538-1541.
$182 \mathrm{Hu}$ X, Lee JS, Pianosi PT, Ryu JH: Aspiration-related pulmonary syndromes. Chest 2015;147:815-823.

183 Marie I, Ménard JF, Hachulla E, Chérin P, Benveniste O, Tiev K, Hatron PY: Infectious complications in polymyositis and dermatomyositis: a series of 279 patients. Semin Arthritis Rheum 2011;41:48-60.

184 Gyger G, Baron M: Gastrointestinal manifestations of scleroderma: recent progress in evaluation, pathogenesis, and management. Curr Rheumatol Rep 2012;14:22-29.

185 Hansi N, Thoua N, Carulli M, Chakravarty K, Lal S, Smyth A, Herrick A, Ogunbiyi O, Shaffer J, Mclaughlin J, Denton C, Ong V, Emmanuel AV, Murray CD: Consensus best practice pathway of the UK scleroderma study group: gastrointestinal manifestations of systemic sclerosis. Clin Exp Rheumatol 2014;32(suppl 86):S-214-S-221.

186 Bharadwaj S, Tandon P, Gohel T, Corrigan ML, Coughlin KL, Shatnawei A, Chatterjee S, Kirby DF: Gastrointestinal manifestations, malnutrition, and role of enteral and parenteral nutrition in patients with scleroderma. J Clin Gastroenterol 2015;49:559-564.

-187 Baron M, Hudson M, Dagenais M, MacDonald D, Gyger G, El Sayegh T, Pope J, Fontaine A, Masetto A, Matthews D, Sutton E, Thie N, Jones N, Copete M, Kolbinson D, Markland J, Nogueira-Filho G, Robinson D, Fritzler M, Gornitsky M: The Canadian Systemic Sclerosis Oral Health Study V: relationship between disease characteristics and oral radiologic findings in systemic sclerosis. Arthritis Care Res (Hoboken) 2015, Epub ahead of print.

188 Marie I, Ménard JF, Hatron PY, Hachulla E, Mouthon L, Tiev K, Ducrotte P, Chérin P: Intravenous immunoglobulins for steroidrefractory esophageal involvement related to polymyositis and dermatomyositis: a series of 73 patients. Arthritis Care Res (Hoboken) 2010;62:1748-1755.

189 Marik PE: Aspiration pneumonitis and aspiration pneumonia. N Engl J Med 2001;344: 665-677.

190 Roman MJ, Salmon JE: Cardiovascular manifestations of rheumatologic diseases. Circulation 2007;116:2346-2355

191 Dave AJ, Fiorentino D, Lingala B, Krishnan E, Chung L: Atherosclerotic cardiovascular disease in hospitalized patients with systemic sclerosis: higher mortality than patients with lupus and rheumatoid arthritis. Arthritis Care Res (Hoboken) 2014;66:323-327.

192 Nurmohamed MT, Heslinga M, Kitas GD: Cardiovascular comorbidity in rheumatic diseases. Nat Rev Rheumatol 2015;11:693704.

193 Sagar S, Liu PP, Cooper LT Jr: Myocarditis. Lancet 2012;379:738-747.

194 Voskuyl AE: The heart and cardiovascular manifestations in rheumatoid arthritis. Rheumatology (Oxford) 2006;45(suppl 4): iv4-iv7.
95 Miner JJ, Kim AHJ: Cardiac manifestations of systemic lupus erythematosus. Rheum Dis Clin North Am 2014;40:51-60.

196 Papadakis JA, Sidiropoulos PI, Karvounaris SA, Vrentzos GE, Spanakis EK, Ganotakis ES, Kritikos HD, Mikhailidis DP, Boumpas DT: High prevalence of metabolic syndrome and cardiovascular risk factors in men with ankylosing spondylitis on anti-TNFa treatment: correlation with disease activity. Clin Exp Rheumatol 2009;27:292-298.

197 Man A, Zhu Y, Zhang Y, Dubreuil M, Rho YH, Peloquin C, Simms RW, Choi HK: The risk of cardiovascular disease in systemic sclerosis: a population-based cohort study. Ann Rheum Dis 2013;72:1188-1193.

198 Mok MY, Lau CS: The burden and measurement of cardiovascular disease in SSc. Nat Rev Rheumatol 2010;6:430-434.

199 Fernandes N, Gomes G, Capela C: Presentation of systemic lupus erythematosus (SLE) in emergency department: a case report. BMC Res Notes 2013;6:181.

200 Rosenbaum E, Krebs E, Cohen M, Tiliakos A, Derk CT: The spectrum of clinical manifestations, outcome and treatment of pericardial tamponade in patients with systemic lupus erythematosus: a retrospective study and literature review. Lupus 2009;18:608-612.

201 Shimizu T, Murata M, Tomizawa H, Mitsuhashi T, Katsuki T, Shimada K: Systemic lupus erythematosus initially manifesting as acute pericarditis complicating with cardiac tamponade: a case report. J Cardiol 2007;49: 273-276.

202 Adler Y, Charron P, Imazio M, Badano L, Barón-Esquivias G, Bogaert J, Brucato A, Gueret P, Klingel K, Lionis C, Maisch B, Mayosi B, Pavie A, Ristić AD, Sabaté Tenas M, Seferovic P, Swedberg K, Tomkowski W, Achenbach S, Agewall S, Al-Attar N, Angel Ferrer J, Arad M, Asteggiano R, Bueno H, Caforio AL, Carerj S, Ceconi C, Evangelista A, Flachskampf F, Giannakoulas G, Gielen S, Habib G, Kolh P, Lambrinou E, Lancellotti P, Lazaros G, Linhart A, Meurin P, Nieman K, Piepoli MF, Price S, Roos-Hesselink J, Roubille F, Ruschitzka F, Sagristà Sauleda J, SousaUva M, Uwe Voigt J, Luis Zamorano J; European Society of Cardiology (ESC): 2015 ESC Guidelines for the diagnosis and management of pericardial diseases. The Task Force for the Diagnosis and Management of Pericardial Diseases of the European Society of Cardiology (ESC), endorsed by the European Association for Cardio-Thoracic Surgery (EACTS). Eur Heart J 2015;36:2921-2964.

203 Mavrogeni S, Sfikakis PP, Dimitroulas T, Koutsogeorgopoulou L, Karabela G, Katsifis G, Stavropoulos E, Gialafos E, Spiliotis G, Kolovou G, Kitas GD: Imaging patterns of cardiovascular involvement in mixed connective tissue disease evaluated by cardiovascular magnetic resonance. Inflamm Allergy Drug Targets 2016, Epub ahead of print. 
204 Imadachi H, Imadachi S, Koga T, Miyashita $\mathrm{T}$, Izumi $\mathrm{Y}$, Takayama $\mathrm{H}$, Nakamichi $\mathrm{C}$, Hamawaki M, Yamaguchi H, Matsukuma S, Ito M, Maeda K, Motokawa S, Sasaki O, Migita: Successful treatment of refractory cardiac tamponade due to rheumatoid arthritis using pericardial drainage. Rheumatol Int 2010;30:1103-1106.

-205 Prasad M, Hermann J, Gabriel SE, Weyand CM, Mulvagh S, Mankad R, Oh JK, Matteson EL, Lerman A: Cardiorheumatology: cardiac involvement in systemic rheumatic disease. Nat Rev Cardiol 2015;12:168-176.

206 Ikdahl E, Rollefstad S, Olsen IC, Kvien TK, Hansen IJ, Soldal DM, Haugeberg G, Semb AG: EULAR task force recommendations on annual cardiovascular risk assessment for patients with rheumatoid arthritis: an audit of the success of implementation in a rheumatology outpatient clinic. Biomed Res Int 2015;2015:515280.

207 Perk J, De Backer G, Gohlke H, Graham I, Reiner Z, Verschuren M, Albus C, Benlian P, Boysen G, Cifkova R, Deaton C, Ebrahim S, Fisher M, Germano G, Hobbs R, Hoes A, Karadeniz S, Mezzani A, Prescott E, Ryden L, Scherer M, Syvänne M, Scholte OP, Reimer WJ, Vrints C, Wood D, Zamorano JL, Zannad F; European Association for Cardiovascular Prevention and Rehabilitation (EACPR); ESC Committee for Practice Guidelines (CPG): European Guidelines on cardiovascular disease prevention in clinical practice (version 2012). The Fifth Joint Task Force of the European Society of Cardiology and Other Societies on Cardiovascular Disease Prevention in Clinical Practice (constituted by representatives of nine societies and by invited experts). Eur Heart J 2012;33: 1635-1701.

-208 Meyer KC, Decker C, Baughman R: Toxicity and monitoring of immunosuppressive therapy used in systemic autoimmune diseases. Clin Chest Med 2010;31:565-588.

209 Camus P, Fanton A, Bonniaud P, Camus C, Foucher P: Interstitial lung disease induced by drugs and radiation. Respiration 2004;71: 301-326.
210 www.pneumotox.com (accessed February 5, 2016).

211 Kubo K, Azuma A, Kanazawa M, Kameda H, Kusumoto M, Genma A, Saijo Y, Sakai F, Sugiyama Y, Tatsumi K, Dohi M, Tokuda H, Hashimoto S, Hattori N, Hanaoka M, Fukuda Y; Japanese Respiratory Society Committee for Formulation of Consensus Statement for the Diagnosis and Treatment of DrugInduced Lung Injuries: Consensus statement for the diagnosis and treatment of drug-induced lung injuries. Respir Investig 2013;51:260-277.

212 Camus P, Rosenow EC 3rd (eds): DrugInduced and Iatrogenic Respiratory Disease, ed 1. London, Hodder Arnold, 2010.

213 Marder W, McCune WJ: Advances in immunosuppressive therapy. Semin Respir Crit Care Med 2007;28:398-417.

214 Burton C, Kaczmarski R, Jan-Mohamed R: Interstitial pneumonitis related to rituximab therapy. N Engl J Med 2003;348:2690-2691.

215 Hadjinicolaou AV, Nisar MK, Parfrey H, Chilvers ER, Ostör AJ: Non-infectious pulmonary toxicity of rituximab: a systematic review. Rheumatology (Oxford) 2012;51: 653-662.

216 Hargreaves MR, Mowat AG, Benson MK: Acute pneumonitis associated with low dose methotrexate treatment for rheumatoid arthritis: report of five cases and review of published reports. Thorax 1992;47:628-633.

217 Zisman DA, McCune WJ, Tino G, Lynch JP 3rd: Drug induced pneumonitis: the role of methotrexate. Sarcoidosis Vasc Diffuse Lung Dis 2001;18:243-252.

218 Takeishi M, Akiyama Y, Akiba H, Adachi D, Hirano M, Mimura T: Leflunomide induced acute interstitial pneumonia. J Rheumatol 2005;32:1160-1163.

219 Sakai F, Noma S, Kurihara Y, Yamada H, Azuma A, Kudoh S, Ichikawa Y: Leflunomide-related lung injury in patients with rheumatoid arthritis: imaging features. Mod Rheumatol 2005;15:173-179.
220 Bedrossian CW, Sussman J, Conklin RH, Kahan B: Azathioprine-associated interstitial pneumonitis. Am J Clin Pathol 1984;82: 148-154.

221 Gross DC, Sasaki TM, Buick MK, Light JA: Acute respiratory failure and pulmonary fibrosis secondary to administration of mycophenolate mofetil. Transplantation 1997;64: 1607-1609.

222 Tubach F, Ravaud P, Salmon-Céron D, Petitpain N, Brocq O, Grados F, Guillaume JC, Leport J, Roudaut A, Solau-Gervais E, Lemann M, Mariette X, Lortholary O; Recherche Axée sur la Tolérance des Biothérapies Group: Emergence of Legionella pneumophila pneumonia in patients receiving tumor necrosis factor-alpha antagonists. Clin Infect Dis 2006;43:e95-e100.

223 Kalyoncu U, Karaday O, Akdogan A, Kisacik B, Erman M, Erguven S, Ertenli AI: Pneumocystis carinii pneumonia in a rheumatoid arthritis patient treated with adalimumab. Scand J Infect Dis 2007;39:475-478.

224 Dixon WG, Hyrich KL, Watson KD, Lunt M, Galloway J, Ustianowski A; BSRBR Control Centre Consortium, Symmons DP; BSR Biologics Register: Drug-specific risk of tuberculosis in patients with rheumatoid arthritis treated with anti-TNF therapy: results from the British Society for Rheumatology Biologics Register (BSRBR). Ann Rheum Dis 2010;69:522-528.

225 Strand V, Ahadieh S, French J, Geier J, Krishnaswami S, Menon S, Checchio T, Tensfeldt TG, Hoffman E, Riese R, Boy M, Gómez-Reino JJ: Systematic review and meta-analysis of serious infections with tofacitinib and biologic disease-modifying antirheumatic drug treatment in rheumatoid arthritis clinical trials. Arthritis Res Ther 2015; 17:362.

226 Casanova MJ, Chaparro M, Valenzuela C, Cisneros C, Gisbert JP: Adalimumabinduced interstitial pneumonia in a patient with Crohn's disease. World J Gastroenterol 2015;21:2260-2262. 